\title{
Molecular epidemiology of clinical and carrier strains of methicillin resistant Staphylococcus aureus (MRSA) in the hospital settings of north India
}

\author{
Javid A Dar' ${ }^{1}$, Manzoor A Thoker ${ }^{2}$, Jamal A Khan ${ }^{3}$, Asif Ali ${ }^{4}$, \\ Mohammed A Khan ${ }^{1}$, Mohammed Rizwan ${ }^{5}$, Khalid H Bhat ${ }^{5}$, \\ Mohammad J Dar ${ }^{5}$, Niyaz Ahmed ${ }^{5}$ and Shamim Ahmad*1
}

\begin{abstract}
Address: ${ }^{1}$ Microbiology Division, Institute of Ophthalmology, J. N. Medical College, Aligarh Muslim University, Aligarh, India, ${ }^{2}$ Department of Microbiology, Sher-e-Kashmir Institute of Medical Sciences, Srinagar, India, ${ }^{3}$ Division of Bacteriology, Department of Microbiology J. N. Medical College, Aligarh Muslim University, Aligarh, India, ${ }^{4}$ Department of Biochemistry, J. N. Medical College, Aligarh Muslim University, Aligarh, India and ${ }^{5}$ Laboratory of Molecular and Cell Biology, Centre for DNA Fingerprinting and Diagnostics Hyderabad, India

Email: Javid A Dar - javid@cdfd.org.in; Manzoor A Thoker - manzoor_thakur@rediffmail.com; Jamal A Khan - jamalanono@hotmail.com; Asif Ali - asifali.amu@lycos.com; Mohammed A Khan - mohdazharkhan@yahoo.co.in; Mohammed Rizwan - rizwan@cdfd.org.in; Khalid H Bhat - khalid@cdfd.org.in; Mohammad J Dar - jeelanni@gmail.com; Niyaz Ahmed - niyaz@cdfd.org.in;

Shamim Ahmad* - shamimshamim@rediffmail.com

* Corresponding author
\end{abstract}

Published: I4 September 2006

Annals of Clinical Microbiology and Antimicrobials 2006, 5:22 doi:10.1 I86/I476-07| I-5-22
Received: 12 July 2006

Accepted: 14 September 2006

This article is available from: http://www.ann-clinmicrob.com/content/5/I/22

(c) 2006 Dar et al; licensee BioMed Central Ltd.

This is an Open Access article distributed under the terms of the Creative Commons Attribution License (http://creativecommons.org/licenses/by/2.0), which permits unrestricted use, distribution, and reproduction in any medium, provided the original work is properly cited.

\begin{abstract}
Background: The study was conducted between 2000 and 2003 on 750 human subjects, yielding 850 strains of staphylococci from clinical specimens (575), nasal cultures of hospitalized patients (100) and eye \& nasal sources of hospital workers (50 \& 125 respectively) in order to determine their epidemiology, acquisition and dissemination of resistance genes.

Methods: Organisms from clinical samples were isolated, cultured and identified as per the standard routine procedures. Susceptibility was measured by the agar diffusion method, as recommended by the Nat ional Committee for Clinical Laboratory Standards (NCCLS). The modified method of Birnboin and Takahashi was used for isolation of plasmids from staphylococci. Pulsed-field gel electrophoresis (PFGE) typing of clinical and carrier Methicillin resistant Staphylococcus aureus (MRSA) strains isolated during our study was performed as described previously.

Results: It was shown that $35.1 \%$ of Staphylococcus aureus and $22.5 \%$ of coagulase-negative staphylococcal isolates were resistant to methicillin. Highest percentage of MRSA (35.5\%) was found in pus specimens $(n=|5|)$. The multiple drug resistance of all MRSA $(n=180)$ and Methicillin resistant Coagulase-negative Staphylococcus aureus (MRCNS) $(n=76)$ isolates was detected. In case of both methicillin-resistant as well as methicillin-sensitive Saphylococcal isolates zero resistance was found to vancomycin where as highest resistance was found to penicillin $G$ followed by ampicillin. It was shown that the major reservoir of methicillin resistant staphylococci in hospitals are colonized/infected inpatients and colonized hospital workers, with carriers at risk for developing endogenous infection or transmitting infection to health care workers and patients. The results were confirmed by molecular typing using PFGE by Smal-digestion.
\end{abstract}


It was shown that the resistant markers $\mathrm{G}$ and $\mathrm{T}$ got transferred from clinical S. aureus (JS-105) to carrier S. aureus $(\mathrm{JN}-49)$ and the ciprofloxacin $(\mathrm{C} f)$ and erythromycin $(\mathrm{E})$ resistance seemed to be chromosomal mediated. In one of the experiments, plasmid PJMRIO from Staphylococcus aureus coding for ampicillin $(A)$, gentamicin $(G)$ and amikacin $(A k)$ resistance was transformed into Escherichia coli. The minimal inhibitory concentrations (MICs) for A and G were lower in $E$. coli than in S. aureus. However, the MIC for Ak was higher in E. coli transformants than in S. aureus.

Conclusion: There is a progressive increase in MRSA prevalence and multi-drug resistance in staphylococci. Vancomycin is still the drug of choice for MRSA infections. The major reservoir of methicillin resistant staphylococci in hospitals is colonized/infected inpatients and colonized hospital workers. Resistance transfer from staphylococci to $E$. coli as well as from clinical to carrier staphylococci due to antibiotic stress seemed to be an alarming threat to antimicrobial chemotherapy.

\section{Background}

Staphylococci are one of the important causes of human infections but are also found as non-pathogenic microorganisms in human samples [1-5]. The spectrum of $S$. aureus infections includes toxic shock syndrome [6], food poisoning, meningitis $[6,7]$ as well as dermatological disorders ranging from minor infections and eczema to blisters and scalded skin syndrome [8]. Recent reports have begun to document infections caused by Staphylococcus epidermidis, such as bacterial endocarditis [9] prosthetic heart valve endocarditis [10], bacteraemia, surgical wound infections [11], intravascular catheters [12], postoperative endophathalmitis [13], conjunctivitis and keratitis [14]. Several other coagulase negative staphylococci (CNS) species have been implicated at low incidence in a variety of infections. The CNS species Staphylococcus saprophyticus was often regarded as a more important opportunistic pathogen than S. epidermidis in human urinary tract infections (UTIs), especially in young sexually active females. It was considered to be the second most common cause of acute cystatitis or pyelonephritis in these patients $[15,16]$. The major reservoir of Staphylococci in hospitals are colonized/infected in-patients and colonized hospital workers, with carriers at risk for developing endogenous infection or transmitting infection to health care workers and patients $[3,17-23]$, while transient hand carriage of the organism on the hands of health care workers account for the major mechanism for patient to patient transmission [24].

Methicillin-resistant strains of staphylococci were identified immediately upon the introduction of methicillin into clinical practice. Methicillin-resistant $S$. aureus (MRSA) was initially identified for the first time in 1961 by Jevons $[25,26]$. Since then strains of methicillin-resistant Staphylococcus aureus and methicillin-resistant coagulase-negative staphylococci have spread worldwide $[27,28]$ and have become established inside and outside of the hospital environment [29]. Already multiresistant to different classes of antibiotics, MRSA had been reported to acquire resistance to gentamicin and related aminoglycosides [30] therefore the treatment of infections due to these organisms and their eradication is very difficult. Constant monitoring of these strains is essential in order to control their spread in the hospital environment and transmission to the community.

The present study was undertaken with the aim of determining epidemiology of clinical and carrier staphylococci and molecular studies of their acquisition and dissemination of resistance in a hospital setting in northern India.

\section{Materials and methods}

The study population $(\mathrm{n}=750)$ was divided into healthy personnel $(n=175)$ and patients $(n=575)$ (including 50 medical personnel attending wound infections). For the healthy personnel, 125 hospital workers contributed nasal swabs and 50 hospital works contributed ocular swabs. None of the healthy personnel had taken any kind of antibiotics 7 days before the time of specimen collection. For the patients, 50 patients with wound infections admitted in Orthopedic Surgical Ward of J.N. Medical College, Aligarh Muslim University, Aligarh India, contributing nasal swabs besides pus culture and 525 subjects contributing different clinical sources were included. Informed consent was obtained from all the subjects before sample collection. The Ethical committees of Shere-Kashmir Institute of Medical Sciences, Srinagar and J.N. Medical College, Aligarh Muslim University, Aligarh India approved the study.

\section{Specimen collection}

Organisms from clinical samples were cultured as per the routine procedures. The anterior nares were sampled as follows. A sterile cotton-tipped swab was moistened in a culture tube containing $2 \mathrm{ml}$ of $0.1 \%$ buffered Tween 80 . The swab was wrung out within the tube, swirled inside the anterior nares for five clockwise, and five counter clockwise rotations, reintroduced into the culture tube and wrung out. The ocular swabs were obtained as 
Table I: Resistance profiles ${ }^{a}$ of staphylococcal isolates $(n=850)$ from eyes and other clinical sources in health and disease

\begin{tabular}{|c|c|c|c|c|c|c|}
\hline \multirow{2}{*}{$\begin{array}{l}\text { Antimicrobial Agent } \\
(\mathrm{n}=18)^{\mathrm{b}}\end{array}$} & \multicolumn{6}{|c|}{ Percentage of Resistance ${ }^{c}$ Displayed by } \\
\hline & $\begin{array}{l}\text { S. aureus } \\
\mathrm{n}=5 \mathrm{I} 3(\%)\end{array}$ & $\begin{array}{l}\text { Clinical S. arueus } \\
\mathrm{n}=338(\%)\end{array}$ & $\begin{array}{l}\text { Carrier S. arueus } \\
\mathrm{n}=175(\%)\end{array}$ & $\begin{array}{l}\text { Coagulase-negative } \\
\text { Staphylococci (CNS) } \\
n=337(\%)\end{array}$ & $\begin{array}{l}\text { Clinical CNS } \\
n=237(\%)\end{array}$ & $\begin{array}{l}\text { Carrier CNS } \\
\mathrm{n}=100(\%)\end{array}$ \\
\hline Amikacin & $65(12.7)$ & $47(13.9)$ & $18(10.3)$ & $27(8.0)$ & $27(11.4)$ & $0(0.0)$ \\
\hline Ampicillin & $413(80.5)$ & $275(81.4)$ & $138(78.8)$ & $24 \mid(71.5)$ & $183(77.2)$ & $58(58.0)$ \\
\hline Cefazolin & $190(37.0)$ & 131 (38.8) & $59(33.7)$ & $80(23.7)$ & $64(27.0)$ & $16(16.0)$ \\
\hline Cephalexin & $237(46.2)$ & $165(48.8)$ & $72(4 I .1)$ & $86(25.5)$ & $68(28.7)$ & $18(18.0)$ \\
\hline Cephotaxime & $207(40.3)$ & 145 (42.9) & $62(35.4)$ & $78(23.2)$ & $68(28.7)$ & $16(16.0)$ \\
\hline Chloramphenicol & $22(4.3)$ & $16(4.7)$ & $6(3.4)$ & $17(5.0)$ & $12(5.1)$ & $5(5.0)$ \\
\hline Ciprofloxacin & $103(20.1)$ & $81(24.0)$ & $22(12.6)$ & $75(22.2)$ & $56(23.6)$ & $19(19.0)$ \\
\hline Clindamycin & $79(15.4)$ & $60(17.7)$ & $19(10.9)$ & $7 I(2 I . I)$ & $56(23.6)$ & $15(15.0)$ \\
\hline Co-trimoxazoled & $256(50.0)$ & $175(51.8)$ & $81(46.3)$ & $136(40.3)$ & $104(43.9)$ & $32(32.0)$ \\
\hline Fusidic acid & $18(3.5)$ & $14(4.1)$ & $4(2.3)$ & $12(3.6)$ & $8(3.4)$ & $4(4.0)$ \\
\hline Gentamicin & $172(33.5)$ & $122(36.1)$ & $50(28.6)$ & $90(26.7)$ & $72(30.4)$ & $18(18.0)$ \\
\hline Imipenem & $136(26.5)$ & $97(28.7)^{\prime}$ & $39(23.3)$ & $68(20.2)$ & $54(22.8)$ & $14(14.0)$ \\
\hline Methicilline & $180(35.1)$ & $128(37.9)$ & $52(29.7)$ & $76(22.5)$ & $63(26.6)$ & $13(13.0)$ \\
\hline Penicillin G & $472(92.0)$ & $313(92.6)$ & $159(90.9)$ & $303(89.9)$ & $222(93.7)$ & 81 (8I.0) \\
\hline Rifampin & $97(18.9)$ & $68(20.1)$ & $29(16.6)$ & $41(12.2)$ & $33(13.9)$ & $8(8.0)$ \\
\hline Roxithromycin & $146(24.6)$ & $103(30.5)$ & $43(24.6)$ & $53(15.7)$ & $48(20.2)$ & $8(8.0)$ \\
\hline Tetracycline & $61(11.9)$ & $43(12.7)$ & $18(10.3)$ & $24(7.1)$ & $21(8.9)$ & $3(3.0)$ \\
\hline Vancomycin & $0(0.0)$ & $0(0.0)$ & $0(0.0)$ & $0(0.0)$ & $0(0.0)$ & $0(0.0)$ \\
\hline
\end{tabular}

aln accordance to Performance Standards for Antimicrobial Disk Susceptibility Tests, NCCLS (1998, 1999, 2000, 2002).

bAtleast one antimicrobial agent assayed from a particular class of antibiotics.

cThe intermediate resistant category was included in sensitive category.

d(trimethoprim/sulphamethoxazole).

eMethicillin resistance was confirmed by Oxacillin Salt-agar screening - plate procedure

described previously [31]. Swabs were deposited in tubes containing $2 \mathrm{ml}$ of detergent fluid $(0.1 \%$ buffered Tween 80 ) serially diluted in 10 fold steps. $40 \mu \mathrm{l}$ per dilution was then drop plated onto the $5 \%$ sheep blood agar plates and mannitol salt agar plates (Hi-Media Mumbai, India), and the plates were incubated for $24 \mathrm{~h}$ at $35^{\circ} \mathrm{C}$ and observed or the growth of suspected Staphylococci colonies. After the identity of the cultures was confirmed according to Bergey's manual including Gram's staining, catalase and coagulase test (slide and tube methods) [32,33], they were stored at $-70^{\circ} \mathrm{C}$ in freezer vials containing $15 \%$ glycerol for further analysis.

\section{Antimicrobial susceptibility test}

Susceptibility was measured by the agar diffusion method, as recommended by the National Committee for Clinical Laboratory Standards (NCCLS) [34], with the following discs; amikacin (Ak), $30 \mu \mathrm{g}$; ampicillin (A), $10 \mu \mathrm{g}$; cefazolin $(\mathrm{Cz}), 30 \mu \mathrm{g}$; cephalexin $(\mathrm{Ce}), 30 \mu \mathrm{g}$; cephotaxime (Cp), $30 \mu \mathrm{g}$; chloramphenicol (C), $30 \mu \mathrm{g}$; ciprofloxacin (Cf), $5 \mu \mathrm{g}$; clinadamycin (Cd), $2 \mu \mathrm{g}$; Cotrimoxazole (Co), $25 \mu \mathrm{g}$; fusidic acid (Fc), $10 \mu \mathrm{g}$; gentamicin (G), $10 \mu \mathrm{g}$; Imipenem (I), $10 \mu \mathrm{g}$; methicillin (M), $5 \mu \mathrm{g}$; penicillin $\mathrm{G}(\mathrm{P}), 10 \mathrm{U}$; rifampin (R), $5 \mu \mathrm{g}$; roxithromycin (Ro), $30 \mu \mathrm{g}$; Tetracycline (T), $30 \mu \mathrm{g}$; and vancomycin, $30 \mu \mathrm{g}$; (Hi Media Mumbai, India). Methicillin- resistant Staphylococci were also tested for oxacillin resistance using the oxacillin-salt screening test performed according to NCCLS guidelines [35]. S. aureus ATCC $^{\oplus}$ 29213, S. aureus ATCC $^{\circledast}$ 43300; (American Type Culture Collection Manassas, VA USA) were used as the positive and negative controls respectively.

\section{Plasmid isolation, transformation and conjugation}

The modified method of Birnboin and Takahashi was used for isolation of plasmids from staphylococci $[36,37]$. The resulting samples were separated on agarose gels and visualized under UV illumination after staining with ethidium bromide [38]. In order to study the transfer of resistance genes between different species of bacteria, transformation of plasmid DNA from Staphylococcus aureus (JMR-10) $\left(\mathrm{A}^{\mathrm{R}}, \mathrm{G}^{\mathrm{R}}, \mathrm{Ak}^{\mathrm{R}}\right)$ (Table 2) to Escherichia coli $(\mathrm{DH} 5 \alpha)\left(\mathrm{A}^{\mathrm{S}}, \mathrm{G}^{\mathrm{S}}, \mathrm{Ak}^{\mathrm{S}}\right)$ was performed as studied previously [39]. Plasmid DNA was isolated from JMR-10 strain and transformed to DH5 $\alpha$. Transformation was tested by antibiotic sensitivity tests as studied previously [34].

For resistance transfer to be studied through cell - to - cell contacts between clinical and carrier $S$. aureus strains, the conjugation was performed through mixed culture tests as studied previously $[33,39]$. Here S. aureus strains were isolated from a patient having postoperative ocular infection 
Table 2: Antibiotic resistance profiles of $6 \mathrm{I}$ strains of MRSA isolated in an orthopaedic surgical ward

\begin{tabular}{|c|c|c|c|}
\hline Pattern & Antibiotic resistance profiles of MRSA & No. of resistance markers & Strains \\
\hline I. & $\mathrm{A}, \mathrm{Cz}, \mathrm{Ce}, \mathrm{Cp}_{\mathrm{p}} \mathrm{Co}_{\mathrm{N}} \mathrm{G}, \mathrm{I}, \mathrm{M}, \mathrm{P}, \mathrm{R}, \mathrm{Ro}, \mathrm{T}$ & 12 & JMR-I \\
\hline 2. & $\mathrm{Ak}, \mathrm{A}, \mathrm{Cz}, \mathrm{Ce}, \mathrm{Cp}_{\mathrm{p}}, \mathrm{Cf}, \mathrm{Cd}, \mathrm{Co}, \mathrm{G}, \mathrm{I}, \mathrm{M}, \mathrm{P}, \mathrm{Ro}$ & 13 & JMR-2 \\
\hline 3. & $\mathrm{Ak}, \mathrm{A}, \mathrm{Cz}, \mathrm{Ce}, \mathrm{Cp}_{\mathrm{p}} \mathrm{Co}, \mathrm{G}, \mathrm{I}, \mathrm{M}, \mathrm{P}, \mathrm{Ro}$ & 11 & JMR-3, 55, 33, 59 \\
\hline 4. & $\mathrm{~A}, \mathrm{Cz}, \mathrm{Ce}, \mathrm{Cp}_{\mathrm{p}}, \mathrm{Cd}, \mathrm{Co}, \mathrm{G}, \mathrm{I}, \mathrm{M}, \mathrm{P}, \mathrm{T}$ & 11 & JMR-4 \\
\hline 5. & $\mathrm{~A}, \mathrm{Cz}, \mathrm{Ce}, \mathrm{Cp}_{\mathrm{p}} \mathrm{Cd}, \mathrm{Co}, \mathrm{G}, \mathrm{M}, \mathrm{P}$ & 9 & JMR-5 \\
\hline 6. & $\mathrm{~A}, \mathrm{Cz}, \mathrm{Ce}, \mathrm{Cp}, \mathrm{Cf}, \mathrm{Cd}, \mathrm{Co}, \mathrm{G}, \mathrm{M}, \mathrm{P}, \mathrm{R}, \mathrm{Ro}$ & 12 & JMR-6, 38, 5 I \\
\hline 7. & $\mathrm{~A}, \mathrm{Cz}, \mathrm{Ce}, \mathrm{Cp}_{\mathrm{p}}, \mathrm{Cf}, \mathrm{Co}, \mathrm{M}, \mathrm{P}, \mathrm{R}, \mathrm{Ro}$ & 10 & JMR-7 \\
\hline 8. & $\mathrm{Ce}, \mathrm{Cd}, \mathrm{Co}, \mathrm{M}, \mathrm{P}, \mathrm{R}$ & 6 & JMR-8 \\
\hline 9. & $\mathrm{~A}, \mathrm{Cz}, \mathrm{Ce}, \mathrm{Cp}_{\mathrm{p}}, \mathrm{C}, \mathrm{Cd}, \mathrm{Co}, \mathrm{M}, \mathrm{P}, \mathrm{R}$ & 10 & JMR-9 \\
\hline 10. & $\mathrm{Ak}, \mathrm{A}, \mathrm{Cz}, \mathrm{Ce}, \mathrm{C}_{\mathrm{P}}, \mathrm{Cf}, \mathrm{Co}_{\mathrm{N}} \mathrm{G}, \mathrm{M}, \mathrm{P}, \mathrm{R}, \mathrm{Ro}, \mathrm{T}$ & 13 & JMR-10 \\
\hline II. & $\mathrm{Ak}, \mathrm{A}, \mathrm{Cz}, \mathrm{Ce}, \mathrm{Cp}_{\mathrm{p}}, \mathrm{Cd}, \mathrm{Co}, \mathrm{G}, \mathrm{M}, \mathrm{P}, \mathrm{R}, \mathrm{Ro}$ & 12 & JMR-II, 53 \\
\hline 12. & $\mathrm{Ak}, \mathrm{A}, \mathrm{Cz}, \mathrm{Ce}, \mathrm{Cf}, \mathrm{Cd}, \mathrm{Co}, \mathrm{G}, \mathrm{I}, \mathrm{M}, \mathrm{P}, \mathrm{R}, \mathrm{Ro}$ & 13 & JMR-12 \\
\hline 13. & $\mathrm{~A}, \mathrm{Cz}, \mathrm{Ce}, \mathrm{Cp}_{\mathrm{p}} \mathrm{Cd}, \mathrm{Co}, \mathrm{G}, \mathrm{M}, \mathrm{P}, \mathrm{R}$ & 10 & JMR-13 \\
\hline 14. & $\mathrm{~A}, \mathrm{Cz}, \mathrm{Ce}, \mathrm{Cp}, \mathrm{Co}, \mathrm{M}, \mathrm{P}, \mathrm{R}$ & 8 & JMR-I4 \\
\hline 15. & $\mathrm{~A}, \mathrm{Cz}, \mathrm{Ce}, \mathrm{Cp}_{\mathrm{p}} \mathrm{Cf}, \mathrm{Co}, \mathrm{G}, \mathrm{M}, \mathrm{P}, \mathrm{R}$ & 10 & JMR-I5, 58 \\
\hline 16. & $\mathrm{~A}, \mathrm{Cz}, \mathrm{Ce}, \mathrm{Cp}, \mathrm{Cf}, \mathrm{Co}, \mathrm{G}, \mathrm{M}, \mathrm{P}$ & 9 & JMR-16 \\
\hline 17. & $\mathrm{Ak}, \mathrm{A}, \mathrm{Cz}, \mathrm{Ce}, \mathrm{C}_{\mathrm{P}}, \mathrm{Cd}, \mathrm{Co}, \mathrm{G}, \mathrm{M}, \mathrm{P}, \mathrm{R}$ & 11 & JMR-17 \\
\hline 18. & $\mathrm{~A}, \mathrm{Cz}, \mathrm{Ce}, \mathrm{C}_{\mathrm{p}}, \mathrm{Co}_{\mathrm{G}} \mathrm{G}, \mathrm{M}, \mathrm{P}, \mathrm{R}$ & 9 & JMR-18 \\
\hline 19. & $\mathrm{Ak}, \mathrm{A}, \mathrm{Cz}, \mathrm{Ce}, \mathrm{Cp}_{\mathrm{p}}, \mathrm{Co}, \mathrm{G}, \mathrm{M}, \mathrm{P}, \mathrm{Ro}$ & 10 & JMR-19,6I \\
\hline 20. & $\mathrm{Ak}, \mathrm{A}, \mathrm{Cz}, \mathrm{Ce}, \mathrm{C}_{\mathrm{p}}, \mathrm{Cd}, \mathrm{Co}, \mathrm{G}, \mathrm{I}, \mathrm{M}, \mathrm{P}, \mathrm{R}, \mathrm{Ro}$ & 13 & JMR-20 \\
\hline 21. & $\mathrm{~A}, \mathrm{Ce}, \mathrm{Cp}_{\mathrm{C}} \mathrm{C}, \mathrm{Co}, \mathrm{G}, \mathrm{M}, \mathrm{P}, \mathrm{T}$ & 9 & JMR-2I \\
\hline 22. & $\mathrm{Ak}, \mathrm{A}, \mathrm{Cz}_{\mathrm{C}} \mathrm{C}_{\mathrm{p}}, \mathrm{Co}_{\mathrm{o}}, \mathrm{G}, \mathrm{I}, \mathrm{M}, \mathrm{P}, \mathrm{Ro}, \mathrm{T}$ & 11 & JMR-22 \\
\hline 23. & $\mathrm{~A}, \mathrm{Cz}, \mathrm{Ce}, \mathrm{Cp}_{\mathrm{p}} \mathrm{Co}, \mathrm{G}, \mathrm{M}, \mathrm{P}, \mathrm{Ro}$ & 9 & JMR-23 \\
\hline 24. & $\mathrm{Ak}, \mathrm{A}, \mathrm{Cz}, \mathrm{Ce}, \mathrm{Cp}_{\mathrm{p}}, \mathrm{Cf}, \mathrm{Cd}, \mathrm{Co}, \mathrm{G}, \mathrm{M}, \mathrm{P}, \mathrm{Ro}, \mathrm{T}$ & 13 & JMR-24, 46, 48, 39 \\
\hline 25. & $\mathrm{Ak}, \mathrm{A}, \mathrm{Cz}, \mathrm{Ce}, \mathrm{Cp}, \mathrm{C}, \mathrm{Cf}, \mathrm{Co}, \mathrm{Fc}, \mathrm{G}, \mathrm{I}, \mathrm{M}, \mathrm{R}, \mathrm{Ro}, \mathrm{T}$ & 15 & JMR-25 \\
\hline 26. & $\mathrm{~A}, \mathrm{Cz}, \mathrm{Ce}, \mathrm{Cp}, \mathrm{Co}, \mathrm{G}, \mathrm{M}, \mathrm{P}, \mathrm{Ro}, \mathrm{T}$ & 10 & JMR-26, 52 \\
\hline 27. & $\mathrm{~A}, \mathrm{Cz}, \mathrm{Ce}, \mathrm{Cp}, \mathrm{Co}, \mathrm{G}, \mathrm{M}, \mathrm{P}, \mathrm{Ro}, \mathrm{T}$ & 10 & JMR-27 \\
\hline 28. & $\mathrm{Ak}, \mathrm{A}, \mathrm{Cz}, \mathrm{Ce}, \mathrm{Cp}_{\mathrm{p}}, \mathrm{C}, \mathrm{Cf}, \mathrm{Cd}, \mathrm{Co}, \mathrm{Fc}, \mathrm{G}, \mathrm{I}, \mathrm{M}, \mathrm{P}, \mathrm{R}, \mathrm{Ro}, \mathrm{T}$ & 17 & JMR-28, 60 \\
\hline 29 & $\mathrm{~A}, \mathrm{Cz}, \mathrm{Ce}, \mathrm{C}_{\mathrm{p}}, \mathrm{C}, \mathrm{Cd}, \mathrm{Co}_{\mathrm{N}} \mathrm{G}, \mathrm{M}, \mathrm{P}, \mathrm{R}, \mathrm{Ro}, \mathrm{T}$ & 13 & JMR-29 \\
\hline 30. & $\mathrm{~A}, \mathrm{Cz}, \mathrm{Ce}, \mathrm{Cp}_{\mathrm{f}}, \mathrm{Co}, \mathrm{G}, \mathrm{I}, \mathrm{M}, \mathrm{P}, \mathrm{R}, \mathrm{Ro}$ & 11 & JMR-30 \\
\hline 31. & $\mathrm{Ce}, \mathrm{Cp}_{\mathrm{p}} \mathrm{Cd}, \mathrm{Co}, \mathrm{M}, \mathrm{P}$ & 6 & JMR-3I, 56 \\
\hline 32. & $\mathrm{~A}, \mathrm{Cz}, \mathrm{Ce}, \mathrm{Cp}_{\mathrm{p}} \mathrm{Cf}, \mathrm{Co}, \mathrm{G}, \mathrm{M}, \mathrm{P}, \mathrm{R}, \mathrm{Ro}, \mathrm{T}$ & 12 & JMR-32 \\
\hline 33. & $\mathrm{~A}, \mathrm{Cz}, \mathrm{Ce}, \mathrm{Cp}, \mathrm{C}, \mathrm{Cf}, \mathrm{Cd}, \mathrm{G}, \mathrm{Co}, \mathrm{I}, \mathrm{M}, \mathrm{P}, \mathrm{Ro}, \mathrm{T}$ & 14 & JMR-34 \\
\hline 34. & $\mathrm{~A}, \mathrm{Cz}, \mathrm{Ce}, \mathrm{Cp}, \mathrm{C}, \mathrm{Co}, \mathrm{G}, \mathrm{M}, \mathrm{P}, \mathrm{Ro}, \mathrm{T}$ & 11 & JMR-35 \\
\hline 35. & $\mathrm{Ak}, \mathrm{A}, \mathrm{Cz}, \mathrm{Ce}, \mathrm{Cp}_{\mathrm{p}}, \mathrm{C}, \mathrm{Co}, \mathrm{G}, \mathrm{M}, \mathrm{P}, \mathrm{R}, \mathrm{Ro}$ & 12 & JMR-36, 49 \\
\hline 36. & $\mathrm{Cz}, \mathrm{Ce}, \mathrm{Cp}_{\mathrm{p}} \mathrm{Cd}, \mathrm{Co}, \mathrm{M}, \mathrm{P}$ & 7 & JMR-37, 45, 50, 54 \\
\hline 37. & $\mathrm{~A}, \mathrm{Cz}, \mathrm{Ce}, \mathrm{C}_{\mathrm{p}}, \mathrm{Cf}, \mathrm{Co}, \mathrm{M}, \mathrm{P}, \mathrm{R}$ & 9 & JMR-40 \\
\hline 38. & $\mathrm{~A}, \mathrm{Cz}, \mathrm{Ce}, \mathrm{Cp}, \mathrm{C}, \mathrm{Cf}, \mathrm{Cd}, \mathrm{Co}, \mathrm{Fc}, \mathrm{G}, \mathrm{I}, \mathrm{M}, \mathrm{P}, \mathrm{R}, \mathrm{Ro}, \mathrm{T}$ & 16 & JMR-4I \\
\hline 39. & $A k, A, C z, C_{p}, I, M, P, R o$ & 8 & JMR-42 \\
\hline 40. & $\mathrm{~A}, \mathrm{Cz}, \mathrm{Ce}, \mathrm{Cp}_{\mathrm{p}} \mathrm{Cd}, \mathrm{Co}, \mathrm{G}, \mathrm{M}, \mathrm{P}, \mathrm{R}, \mathrm{Ro}$ & 11 & JMR-43 \\
\hline 41. & $\mathrm{~A}, \mathrm{Cz}, \mathrm{Ce}, \mathrm{Cp}, \mathrm{Cf}, \mathrm{Co}, \mathrm{G}, \mathrm{M}, \mathrm{P}, \mathrm{Ro}$ & 10 & JMR-44 \\
\hline 42. & $\mathrm{~A}, \mathrm{Cz}, \mathrm{Ce}, \mathrm{Cp}_{\mathrm{p}} \mathrm{Co}, \mathrm{G}, \mathrm{M}, \mathrm{P}, \mathrm{Ro}$ & 9 & JMr-47, 57 \\
\hline
\end{tabular}

admitted in the postoperative ward of the Institute of Ophthalmology. JN-49 strain $\left(\mathrm{A}^{\mathrm{R}}, \mathrm{P}^{\mathrm{R}}, \mathrm{Cf}^{\mathrm{R}}, \mathrm{E}^{\mathrm{R}}, \mathrm{G}^{\mathrm{S}}, \mathrm{T}^{\mathrm{S}}\right)$ was isolated from the nose of the same patient having postoperative ocular infection and JS-105 ( $\left.\mathrm{T}^{\mathrm{R}}, \mathrm{E}^{\mathrm{R}}, \mathrm{G}^{\mathrm{R}}, \mathrm{A}^{\mathrm{S}}, \mathrm{P}^{\mathrm{S}}, \mathrm{Cf}^{\mathrm{S}}\right)$ was isolated from ocular swab.

\section{PFGE}

Chromosomal DNA from MRSA isolates was prepared in agarose blocks and was cleaved with SmaI (Bangalore Genei Pvt. Ltd. India) as described by Bannerman et al [40]. PFGE typing of clinical and carrier MRSA strains isolated during our study was performed as described previously $[39,41]$. For restriction endonuclease digestion, approximately 1 to $1.5 \mathrm{~mm}$ of a plug was cut and incubated with $250 \mu \mathrm{l}$ of restriction buffer containing $20 \mathrm{U}$ of SmaI at $25^{\circ} \mathrm{C}$ for $4 \mathrm{~h}$. After DNA digestion, the agarose plugs were incubated with $1 \mathrm{ml}$ of TE buffer at $37^{\circ} \mathrm{C}$ for 1 $\mathrm{h}$. The plugs were then inserted into $1 \%$ agorose gel in $0.5 \times \mathrm{TBE}$ buffer, and restriction fragments were separated using a contour-clamped homogeneous electric field system (CHEF-DRII; Bio-Rad, Laboratories). Electrophoresis was performed using the following conditions: Block 1: initial switch time $5 \mathrm{sec}$; final switch time $15 \mathrm{sec}$; run time $10 \mathrm{~h}$; voltage $200 \mathrm{~V}$ or $6 \mathrm{~V} / \mathrm{cm}$. Block 2: initial switch time $15 \mathrm{sec}$, final switch time $60 \mathrm{sec}$. run time $13 \mathrm{~h}$, voltage 20 $\mathrm{V}$ or $6 \mathrm{~V} / \mathrm{cm}$. 


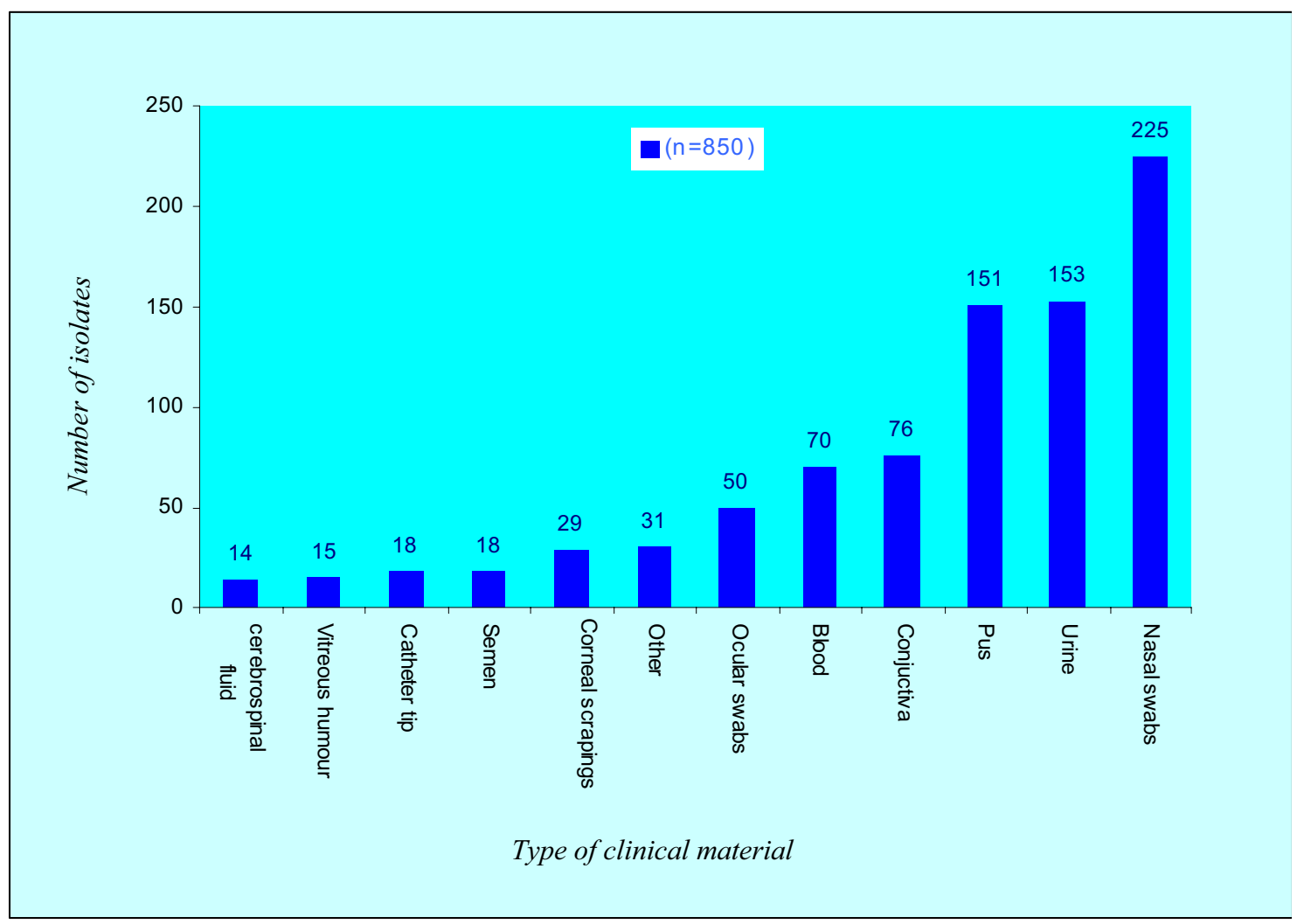

\section{Figure I}

Distribution of staphylococcal isolates among the clinical sources. Out of I5I isolates from pus, II 5 were $S$. aureus and 36 were coagulase-negative staphylococci (CNS). Likewise, of 153 isolates from urine, 77 were CNS and 76 were S. aureus. Of the 225 nasal swabs of hospital workers and patients studied, I75 (34. I\%) were S. aureus and 50 (I4.8\%) were CNS.

\section{Results}

\section{Age and gender distribution}

Of the 750 subjects studied the male: female ratio was 52.5:47.5, of whom 175 were normal hospital workers (Table 5). The age range was 5 to 75 years. Of these 12 cases of mastatitis belonged exclusively to females and 18 cases of prostatitis to men. Of patients having wound infections $(\mathrm{n}=122)$, the highest prevalence of Staphylococci $(27 \%)$ was found in the age group of 45-64 years and so was the case with patients having urinary tract infections $(32.6 \%)$. In this study Staphylococcal conjunctivitis was found equally prominent in the age group of 5$14(23.1 \%)$ and $45-64(23.1 \%)$ years. Of the 175 normal hospital workers, the highest number of carrier Staphylococci $(48 \%)$ were isolated from the subjects having age between 25 and 44 years where as the age group 5-14 years contributed none. In the present study we were having no information regarding the age of 52 subjects and so they were categorized as unknown age group.

\section{Frequency of staphylococcal isolates among clinical sources}

Of the 850 clinical strains of staphylococci studied (Table 1), 60.3\% were Staphylococcus aureus and 39.7\% coagulase-negative staphylococci. Of these $35.1 \%$ were methicillin-resistant Staphylococcus aureus (MRSA) and 22.5\% were methicillin-resistant coagulase-negative staphylococci (MRCNS). The highest number of $S$. aureus strains was isolated from pus $(22.7 \%)$ followed by urine $(14.8 \%)$ and blood (11.3\%) (Figure 1). Likewise, the highest number of coagulase-negative staphylococcal isolates was found in urine $(22.8 \%)$ followed by conjunctivitis $(16.3 \%)$ and pus $(10.7 \%)$. Of the 225 nasal swabs of hospital workers and patients studied, $34.1 \%$ were $S$. aureus and $14.8 \%$ were coagulase-negative staphylococci, where as from ocular swabs $(n=50)$ of hospital workers all the strains studied were coagulase-negative staphylococci. Of the 180 MRSA strains the highest number was found in pus (35.5\%) followed by urine (16.1\%) and blood (9.4\%). In 
Table 3: PFGE patterns of $6 I$ MRSA isolates

\begin{tabular}{lll}
\hline Banding pattern & Strains & Number of isolates \\
\hline A & JMR-I, 2, 3, 4, 6, 38, 55 & 7 \\
B & JMR-5, I4, I8 & 3 \\
C & JMR-9, I3, I9, 26, 52 & 5 \\
D & JMR-16, 25, 29 & 3 \\
E & JMR-24, 46, 48, 39 & 4 \\
F & JMR-3I, 56 & 2 \\
G & JMR-37, 50, 54, I5, 58 & 5 \\
H & JMR-2I, 40, 42, 44, 59, 6I & 6 \\
I & JMR-8 & I \\
J & JMR-I7, 20, 23, 27, 30, 32, 6 \\
K & JMR-II, I2, 28, 4I, 53 60, 6 \\
L & JMR-22, 33, 34, 35, 36 & 5 \\
M & JMR-43, 45, 5I & 3 \\
N & JMR-7, 10, 47, 49, 57 & 5 \\
\hline
\end{tabular}

case of nasal swabs of hospital workers and patients ( $\mathrm{n}=$ 225 ) the frequency of MRSA isolates was $28.9 \%$ that is equivalent to MRSA carrier rate of $23.1 \%$. Of the 76 MRCNS studied the highest number was obtained from urine $(25.0 \%)$ followed by conjunctiva (18.4\%) and nasal swabs of patients having ocular infections (14.5\%), where as $10.5 \%$ of MRCNS were isolated from ocular swabs of hospital workers.

\section{Resistance Profiles of Staphylococcal Isolates}

The resistance patterns of staphylococcal isolates $(\mathrm{n}=$ $850)$ to 18 antimicrobial agents are shown in Table 1. Vancomycin appeared to be the most effective drug. In case of Staphylococcus aureus $(\mathrm{n}=513)$, the highest resistance was observed to penicillin G $(92.0 \%)$ followed by ampicillin $(80.5 \%)$ and co-trimoxazole (50.0\%). Though the highest resistance in coagulase-negative staphylococci ( $\mathrm{n}=337$ ) was shown to penicillin $\mathrm{G}(89.9 \%)$ but it was lesser by $(2.1 \%)$ as compared to its resistance in Staphylococcus aureus, followed by the same pattern as to ampicillin $(71.5 \%)$ and co-trimoxazole (40.3\%).

As far as the clinical versus carrier staphylococcal islates are concerned the general observation was that the resistance in carrier isolates was lesser than clinical strains in case of all antibiotics. In clinical $(\mathrm{n}=338)$ and carrier ( $\mathrm{n}$ $=175$ ) isolates of $S$. aureus the highest resistance was

Table 4: Minimal inhibitory concentrations of A, G, Ak for S. aureus strain JMRIO and one $E$. coli transformant

\begin{tabular}{llll}
\hline Strain & \multicolumn{3}{c}{ MIC $(\mu \mathrm{g} / \mathrm{ml})$} \\
\cline { 2 - 4 } & A & $\mathbf{G}$ & $\mathbf{A k}$ \\
\hline S. aureus strain JMRI0 & 800 & 1000 & 200 \\
$\begin{array}{l}\text { E. coli } \\
\text { E. coli transformants }\end{array}$ & $\mathrm{I}$ & $\mathrm{I}$ & 3 \\
& 200 & 100 & 400 \\
\hline
\end{tabular}

found to penicillin G ( $92.6 \%$ versus $90.60 \%$ ) followed by ampicillin (81.4\% versus $78.8 \%$ ) and co-trimoxazole (51.8\% versus $46.3 \%)$ respectively. The least resistance was shown to fusidic acid ( $4.1 \%$ versus 2.3 ) followed by chloramphenicol $(4.7 \%$ versus $3.4 \%)$, tetracycline (12.7\% versus $7.1 \%$ ) and amikacin (13.9\% versus $10.3 \%)$ respectively in clinical and carrier isolates of $S$. aureus. Almost similar trend was observed in clinical $(\mathrm{n}=237)$ and carrier $(\mathrm{n}=100)$ isolates of coagulase-negative staphylococci, with the exception that in carrier isolates zero resistance to amikacin was seen.

\section{Comparative multi-drug resistance patterns of methicillin- resistant and methicillin-sensitive clinical and carrier isolates}

Resistance to 4 antibiotics or more was observed in both S. aureus and Coagulase-negative staphylococci. In case of MRSA isolates, no strain showed resistance to 5 or less than 5 antibiotics, where as all MRCNS strains showed resistance to 8 or more than 8 antibiotics. As far as the clinical and carrier MRSA are concerned, in the present study, both types of strains showed resistance to 6 or more than 6 antibiotics assayed (Fig 2). In case of clinical and carrier methicillin-sensitive $S$. aureus (MSSA) isolates, no strain showed resistance to more than 7 antibiotics.

Almost same trend of multidrug resistance patterns was observed in case of clinical and carrier, MRCNS and MSCNS isolates from eye and other clinical sources in health and diseases (Fig 3).

\section{Antibiotic resistance profiles of MRSA isolates in an orthopedic surgical ward}

In this study, 61 isolates turned to be MRSA, were isolated in an Orthopaedic Surgical Ward from wound infections $(\mathrm{n}=56)$; their nose $(\mathrm{n}=50)$; and nose of hospital workers attending wound infections $(\mathrm{n}=50)$. As depicted in Table 2, MRSA isolates, JMR-8, 31, 56 showed resistance to 6 antibiotics; and one strain showed resistance to 16 antibiotics (JMR-41), and two strains showed resistance to maximum of 17 antibiotics (JMR-28, 60) assayed in the present study. Antibiotic resistance patterns, 3, 24, and 36 were the most common profiles found by 4 strains each in this study.

\section{PFGE profiles of MRSA}

The 14 common methicillin - resistant S. aureus (MRSA) patterns were identified among 61 stains of MRSA isolated in the Orthopedic Surgical Ward (figure 4). The patterns were designated by the letters $\mathrm{A}$ to $\mathrm{N}$ based on difference in banding patterns. The banding type A was shown by highest number of MRSA strains $(\mathrm{n}=7)$, where as type I was shown by only one MRSA isolate (Table 3 ). These results indicated that typing can be performed effectively through molecular techniques such as PFGE patterns but 
Table 5: Age and gender distribution of staphylococcal infected/colonized subjects $(n=750)$ according to clinical diagnosis

\begin{tabular}{|c|c|c|c|c|c|c|c|c|c|c|c|c|}
\hline \multirow{3}{*}{$\begin{array}{l}\text { Clinical Diagnosis } \\
\mathrm{n}=750(100 \%)\end{array}$} & \multicolumn{12}{|c|}{ Age $(Y)$} \\
\hline & \multicolumn{2}{|c|}{$5-14 n=63(\%)$} & \multicolumn{2}{|c|}{$15-24$ n $=133(\%)$} & \multicolumn{2}{|c|}{$25-44 n=224(\%)$} & \multicolumn{2}{|c|}{$45-64 n=182(\%)$} & \multicolumn{2}{|c|}{$>65 n=96(\%)$} & \multicolumn{2}{|c|}{ Unknown $^{\mathrm{a}} \mathrm{n}=52(\%)$} \\
\hline & $\begin{array}{c}\text { Male } \\
\mathrm{n}=31(49.2)\end{array}$ & $\begin{array}{c}\text { Female } \\
\mathrm{n}=32(50.8)\end{array}$ & $\begin{array}{c}\text { Male } \\
\mathrm{n}=67(50.4)\end{array}$ & $\begin{array}{c}\text { Female } \\
\mathrm{n}=66(49.6)\end{array}$ & $\begin{array}{c}\text { Male } \\
\mathrm{n}=116(51.8)\end{array}$ & $\begin{array}{c}\text { Female } \\
\mathrm{n}=108(48.2)\end{array}$ & $\begin{aligned} & \text { Male } \\
\mathrm{n}= & 101(55.5)\end{aligned}$ & $\begin{array}{c}\text { Female } \\
\mathrm{n}=81(44.5)\end{array}$ & $\begin{array}{c}\text { Male } \\
\mathrm{n}=56(58.3)\end{array}$ & $\begin{array}{c}\text { Female } \\
\mathrm{n}=40(41.7)\end{array}$ & $\begin{array}{c}\text { Male } \\
\mathrm{n}=23(44.2)\end{array}$ & $\begin{array}{c}\text { Female } \\
\mathrm{n}=29(55.8)\end{array}$ \\
\hline $\begin{array}{l}\text { Wound infection } \\
\mathrm{n}=122(16.2)\end{array}$ & $8(12.7)$ & $5(7.9)$ & $16(12.0)$ & $14(10.5)$ & $16(7.1)$ & $7(3.1)$ & $17(9.3)$ & $16(8.8)$ & $9(9.4)$ & $7(7.3)$ & $2(3.8)$ & $5(9.6)$ \\
\hline $\begin{array}{l}\text { Postoperative infection } \\
\mathrm{n}=35(4.7)\end{array}$ & I (I.6) & $2(3.2)$ & $2(1.5)$ & $\mathrm{I}(0.7)$ & $2(0.9)$ & $8(3.6)$ & $4(2.2)$ & $5(2.7)$ & $8(8.3)$ & $2(2.1)$ & - & - \\
\hline $\begin{array}{l}\text { Bacteraemia } \\
\mathrm{n}=25(3.3)\end{array}$ & I (I.6) & I (I.6) & - & $2(1.5)$ & $4(1.8)$ & $2(0.9)$ & $7(3.8)$ & $4(2.2)$ & I (I.0) & - & $2(3.8)$ & I (I.9) \\
\hline $\begin{array}{l}\text { Pneumonia } \\
\mathrm{n}=21(2.8)\end{array}$ & $5(7.9)$ & I (I.6) & $\mathrm{I}(0.7)$ & - & I $(0.4)$ & I $(0.4)$ & $\mathrm{I}(0.5)$ & $2(1.1)$ & $3(3.1)$ & I (I.0) & $3(5.8)$ & $2(3.8)$ \\
\hline $\begin{array}{l}\text { Septicaemia } \\
\mathrm{n}=15(2.0)\end{array}$ & - & - & $\mathrm{I}(0.7)$ & $\mathrm{I}(0.7)$ & I (0.4) & $2(0.9)$ & $2(1.1)$ & $2(1.1)$ & I (I.0) & - & $2(3.8)$ & $3(5.8)$ \\
\hline $\begin{array}{l}\text { Urinary tract infections } \\
\mathrm{n}=89(1 \mathrm{l} .9)\end{array}$ & - & I (I.6) & $4(3.0)$ & $5(3.8)$ & $10(4.5)$ & $15(6.7)$ & $14(7.7)$ & $15(8.2)$ & $9(9.4)$ & $\mathrm{II}(\mathrm{II.5)}$ & - & $5(9.6)$ \\
\hline $\begin{array}{l}\text { Mastatitis } \\
\mathrm{n}=12(1.6)\end{array}$ & - & - & - & $2(1.5)$ & - & $8(3.6)$ & - & $2(1.1)$ & - & - & - & - \\
\hline $\begin{array}{l}\text { Prostatitis } \\
\mathrm{n}=18(2.4)\end{array}$ & - & - & I (0.7) & - & $5(2.2)$ & - & $9(4.9)$ & - & $3(3.1)$ & - & - & - \\
\hline $\begin{array}{l}\text { Conjunctivitis } \\
\mathrm{n}=52(6.9)\end{array}$ & $7(11.1)$ & $5(7.9)$ & $5(3.8)$ & $4(3.0)$ & I (0.4) & $4(1.8)$ & $7(3.8)$ & $5(2.7)$ & $4(4.2)$ & $5(5.2)$ & $3(5.8)$ & $2(3.8)$ \\
\hline $\begin{array}{l}\text { Corneal ulcer } \\
\mathrm{n}=20(2.7)\end{array}$ & I (I.6) & - & $2(1.5)$ & - & $2(0.9)$ & I (0.4) & $2(1.1)$ & $3(1.6)$ & $3(3.1)$ & $2(2.1)$ & I (I.9) & $3(5.8)$ \\
\hline $\begin{array}{l}\text { Endophthalmitis } \\
\mathrm{n}=1 \mathrm{I}(\mathrm{I} .5)\end{array}$ & - & - & I (0.7) & - & - & I $(0.4)$ & $2(1.1)$ & $2(1.1)$ & $2(2.1)$ & I (I.0) & I (I.9) & I (I.9) \\
\hline $\begin{array}{l}\text { Otherb } \\
\mathrm{n}=110(14.7)\end{array}$ & $8(12.7)$ & $13(20.6)$ & II (8.3) & $13(9.8)$ & $12(5.3)$ & $8(3.6)$ & $12(6.6)$ & $8(4.4)$ & II (II.5) & $9(9.4)$ & $3(5.8)$ & $2(3.8)$ \\
\hline $\begin{array}{l}\text { Normalc } \\
\mathrm{n}=175(23.3)\end{array}$ & - & - & $20(15.0)$ & $18(13.5)$ & $56(25.0)$ & $46(20.5)$ & $16(8.8)$ & I 5 (8.2) & - & - & $2(3.8)$ & $2(3.8)$ \\
\hline $\begin{array}{l}\text { Unknownd } \\
\mathrm{n}=45(6.0)\end{array}$ & - & $4(6.3)$ & $3(2.2)$ & $6(4.5)$ & $6(2.7)$ & $5(2.2)$ & $8(4.4)$ & $2(1.1)$ & $2(2.1)$ & $2(2.1)$ & $4(7.7)$ & $3(5.8)$ \\
\hline
\end{tabular}

aAge not recorded for 52 subjects.

bAbscess or osteomyelitis, cystitis, peritonitis, endocarditis, toxic shock syndrome, keratitis, etc.

cStrains isolated from nose of hospital workers attending wound infections $(n=50)$, nose of hospital workers $(n=75)$ and normal eyes of hospital workers $(n=50)$ respectively in Orthopaedic Surgical Ward of J.N Medical College, A.M.U., Aligarh, S.K. Institute of Medical Sciences Kashmir and Surgical Wards of Institute of Ophthalmology, A.M.U. Aligarh.

dClinical diagnosis not recorded for 45 subjects. 


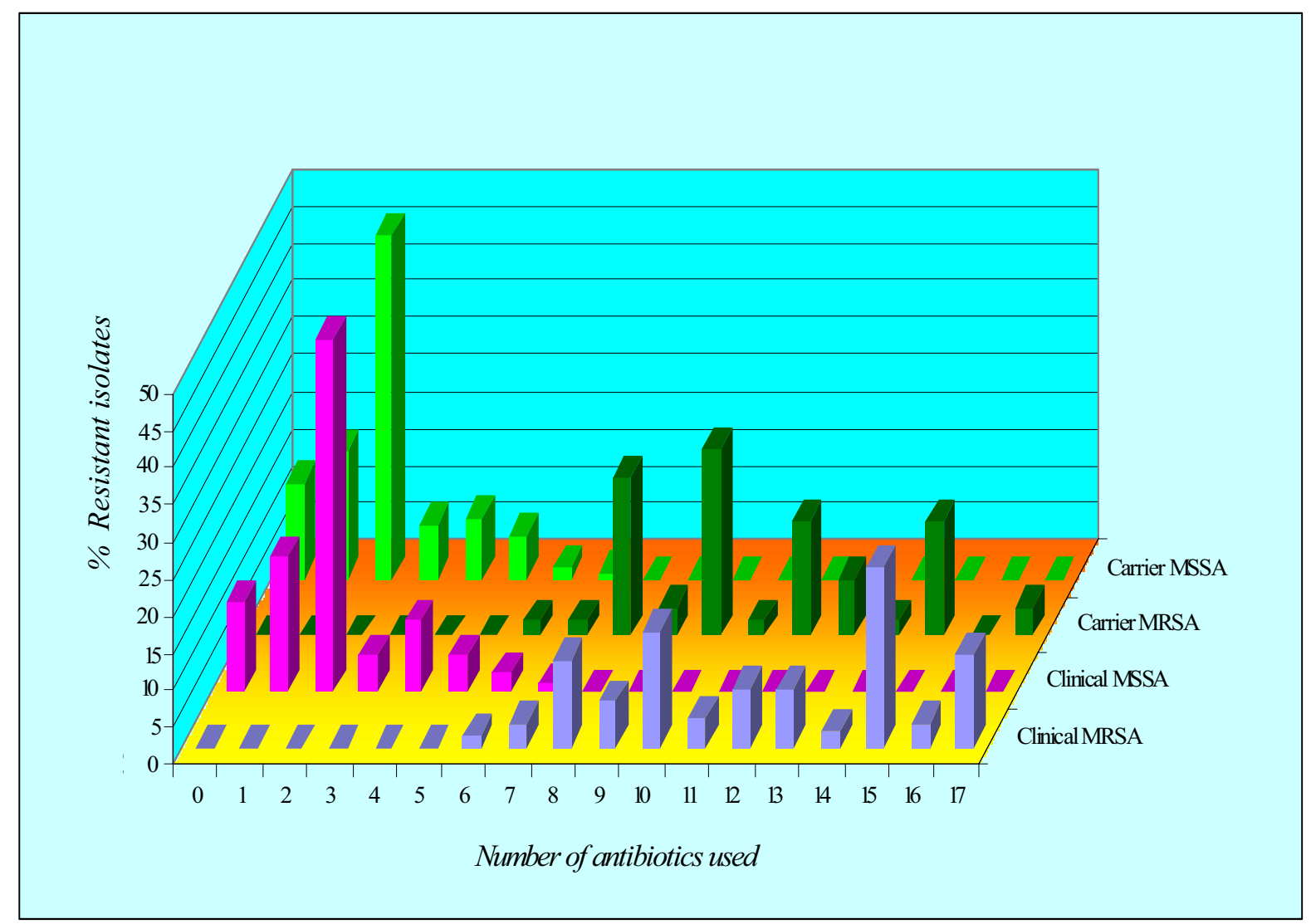

Figure 2

Occurrence of multidrug resistance in methicillin-resistant and methicillin-sensitive $S$. aureus clinical and carrier isolates.

not through antibiograms as 61 strains showed 42 antibiograms that were narrowed down to only 14 types by PFGE. Moreover, it is evident that the MRSA strains which display a common antibiogram can not necessarily show the same PFGE pattern, for example, JMR-3, 55, 33, 59 showed antibiogram 3 (Table 3 ) but JMR-33 showed PFGE pattern L and JMR-59 showed PFGE pattern $H$ although both JMR-3 and JMR-55 showed the same PFGE pattern A.

Molecular typing by PFGE of SmaI-digested DNA from MRSA strains isolated from eight patients having postoperative wound infections admitted in Orthopedic Surgical Ward was performed (Fig 5). The staphylococcal strains were isolated from pus, skin and nose of the patients. The criteria proposed by Tenover et al [41] were employed to analyze the DNA fingerprints generated by PFGE. PFGE patterns are indistinguishable between MRSA from the nasal cavity (A1, A1), and pus (A1, A1) but the pattern is different for MRSA from the skin (B, E) nearby wounds for cases 1 and 8 , respectively. PFGE patterns are indistinguishable between MRSA from the nasal cavity (C1) and
Pus (C1) and closely related to that of MRSA from the skin (C2) for case 2 (Fig. 5). PFGE patterns are indistinguishable between MRSA from the skin (C4) and pus (C4) but closely related to that of MRSA from the nasal cavity (C2) for case 7 . The patterns of MRSA isolates from the pus, skin and nasal cavity are indistinguishable for cases 3 (A2, $\mathrm{A} 2, \mathrm{~A} 2), 4(\mathrm{C} 3, \mathrm{C} 3, \mathrm{C} 3), 5(\mathrm{C} 3, \mathrm{C} 3, \mathrm{C} 3)$ and 6 (D, D, D). These results indicated that self-infection through colonization needs to be taken into consideration and the appropriate measures should be followed to minimize the role of carrier isolates in postoperative infections.

Furthermore the bacteria that normally colonize the human body (the resident microflora) could act as reservoirs for resistance genes, which could then be transferred to pathogens during their temporary colonization of the same site, and need to be focused while treating infections.

\section{Plasmid-determined resistance transfer}

The E. coli (DH5 $\alpha$ ), which was earlier sensitive to Ampicillin (A), Gentamicin (G) and Amikacin (Ak), now acquired 


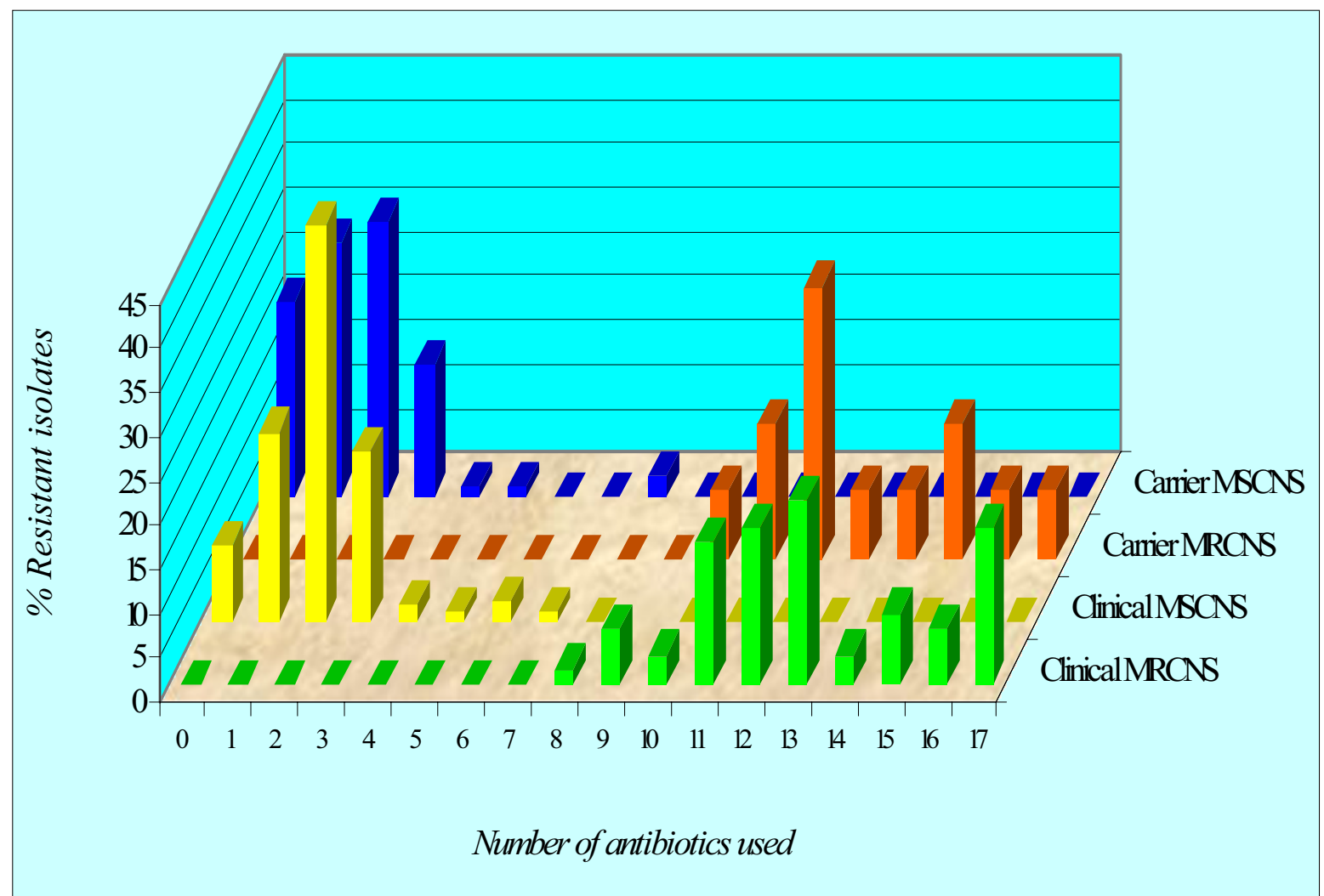

Figure 3

Occurrence of multidrug resistance in methicillin-resistant and methicillin-sensitive coagulase-negative staphylococcal clinical and carrier Isolates.

resistance to these three antibiotics after transformation of plasmid pJMR-10 into it. Again plasmid was isolated from transformed E. coli (DH5 $\alpha$ ) and the isolated plasmid preparation from $S$. aureus (JMR-10) and transformed $E$. coli (DH5 $\alpha$ ) were loaded in $0.7 \%$ agarose gel. From Fig. 6 it appeared that the $4.3 \mathrm{~kb}$ plasmid from $S$. aureus (Lane A) was transformed to E. coli (Lane C). Minimum inhibitory concentrations of A, G, Ak on S. aureus strain JMR-10 and E. coli transformant indicated (Table 4) that the MIC for Ak was higher in E. coli than S. aureus and may be due to the fact that $\mathrm{Ak}$ resistance gene was very efficiently expressed in E. coli.

Plasmids were electrophoresed (Fig. 7) after isolation from JN-49 (Lane A), JS-105 (Lane B), and transconjugant JNS-1 (Lane E). Here transconjugants were screened as $\left(A^{R}, T^{R}\right)$. The transconjugant JNS- 1 was subjected to curing treatment with ethedium bromide. Three types of cured transconjugents were obtained. As shown in figure 7 cured transconjugant JNS-IA (Lane C), having $38 \mathrm{~Kb}$ plasmid showed resistance pattern as $\mathrm{G}^{\mathrm{R}}, \mathrm{E}^{\mathrm{R}}, \mathrm{Cf}^{\mathrm{R}}, \mathrm{T}^{\mathrm{S}}, \mathrm{A}^{\mathrm{S}}, \mathrm{P}^{\mathrm{S}}$. Similimarly cured transconjugant JNS-IB (Lane D), having no plasmid depicted resistance profile as $\mathrm{E}^{\mathrm{R}}, \mathrm{Cf}^{\mathrm{R}}, \mathrm{T}^{\mathrm{S}}, \mathrm{G}^{\mathrm{S}}, \mathrm{A}^{\mathrm{S}}$, $\mathrm{PS}$. Likewise, cured transconjugant JNS-IC (Lane F), having $4.4 \mathrm{~Kb}$ plasmid, displayed resistance pattern as $\mathrm{T}^{\mathrm{R}}, \mathrm{Cf}^{\mathrm{R}}$, $E^{R}, G^{S}, A^{S}, P^{S}$. The conjugation experiments clearly showed that resistant markers $\mathrm{G}$ and $\mathrm{T}$ got transferred from clinical S. aureus (JS-105) to carrier S. aureus (JN-49). Moreover the ciprofloxacin (Cf) and erythromycin (E) resistance seemed to be chromosomal mediated as evidenced in Lane D.

\section{Discussion}

There are reports of emergence and high occurrence of strains resistant to methicillin from various parts of the world [29]. Recent studies have documented the increased costs associated with MRSA infection, as well as the importance of colonization pressure $[42,43]$. Already multiresistant to different classes of antibiotics, MRSA had been reported to acquire resistance to gentamicin and related aminoglycosides [30], therefore the treatment of infections due to these organisms and their eradication is very difficult. Constant monitoring of these strains is essential in order to control their spread in the hospital 


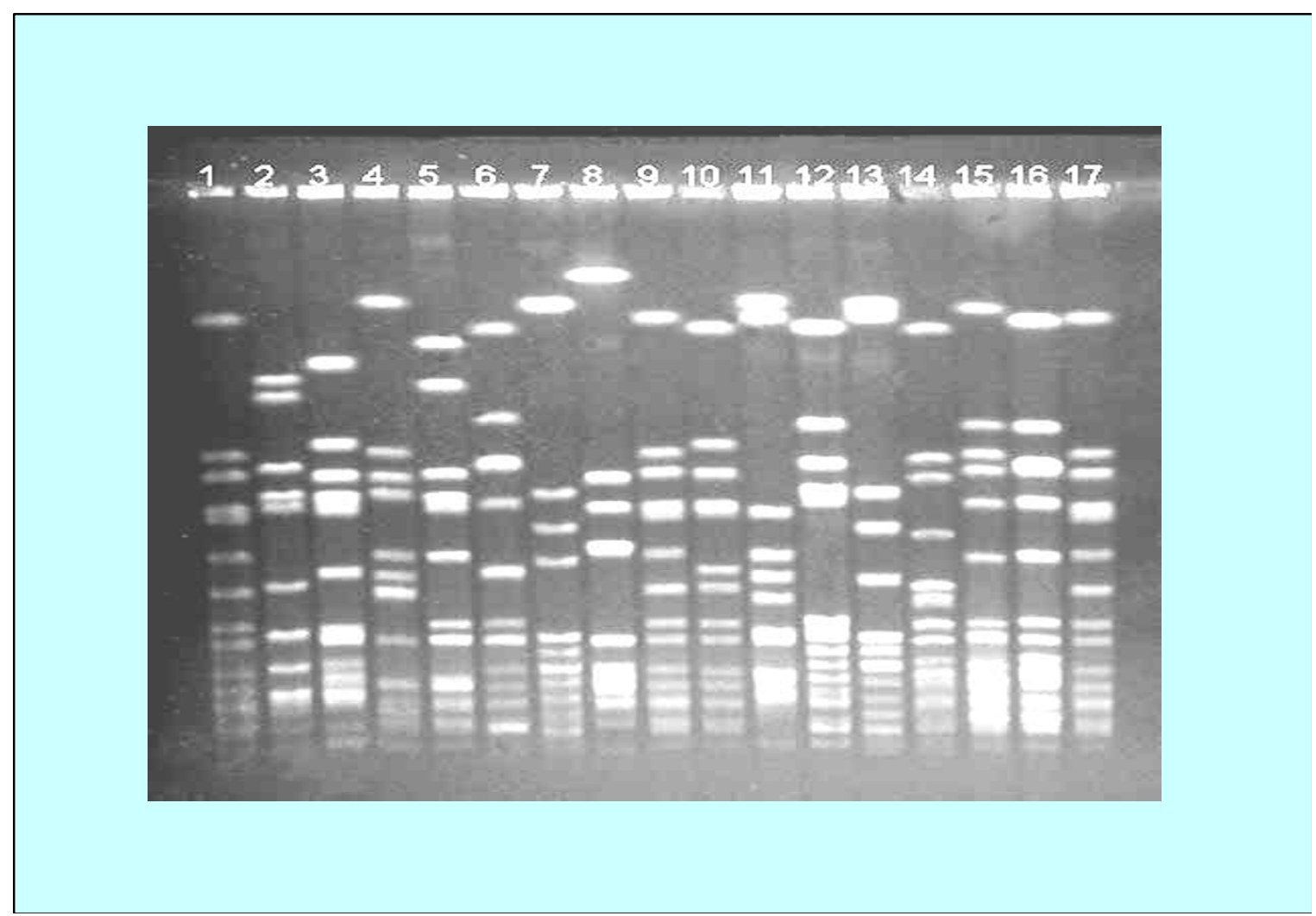

\section{Figure 4}

Pulsed-field gel electrophoresis (PFGE) profiles of MRSA. Fourteen MRSA fingerprint patterns were identified for the 6I strains of MRSA isolated in an Orthopaedic Surgical Ward. These strains were collected from wound infections $(n=56)$; patient's nose $(n=50)$; and nose of the hospital workers attending wound infections $(n=50)$. Lanes I, 9 and I7 represent $S$. aureus 8325 patterns for comparison. Lanes 2 to 16 barring 9 respectively represent PFGE banding patterns $A$ to $N$.

environment and transmission to the community. Of the 513 clinical strains of $S$. aureus, 180 (65.1\%) were methicillin-resistant $S$. aureus (MRSA) and out of 337 coagulasenegative staphylococcal isolates 76 (22.5\%) were methicillin-resistant (MRCNS). Of the 180 MRSA strains the highest number was found in pus followed by urine and blood. Of the 76 MRCNS studied the highest number was obtained from urine followed by conjunctiva and nasal swabs of patients having ocular infections. The number of MRSA isolates being drastically high in wound infections, this might be due to the fact that orthopedic unit is a fertile environment for MRSA. The open wounds and the frequent dressing changes often necessitate a dressing team or multiple persons plus the inherent immunosupression of the wound patients might lead to MRSA colonization.

The present study suggests that MRSA most likely remains a hospital-acquired infection, but a significant proportion may be acquired in community facilities like nursing and residential homes [43]. The major reservoir of staphylococci in hospitals are colonized/infected in-patients and colonized hospital workers, with carriers at risk for developing endogenous infection or transmitting infection to health care workers and patients $[2,3,17-19,44]$, while transient hand carriage of the organism on the hands of health care workers account for the major mechanism for patient to patient transmission [20]. Low prevalence of MRSA colonization in an adult outpatient population indicated that MRSA carriers most likely acquired the organism through contact with healthcare facilities rather than in the community [45]. These data show that care must be taken when attributing MRSA colonization to the community if detected in outpatients or during the first 24 to 48 hours of hospitalization. The risk to patients in terms of transmission of MRSA seems to be influenced strongly by the proportion of patients with col- 


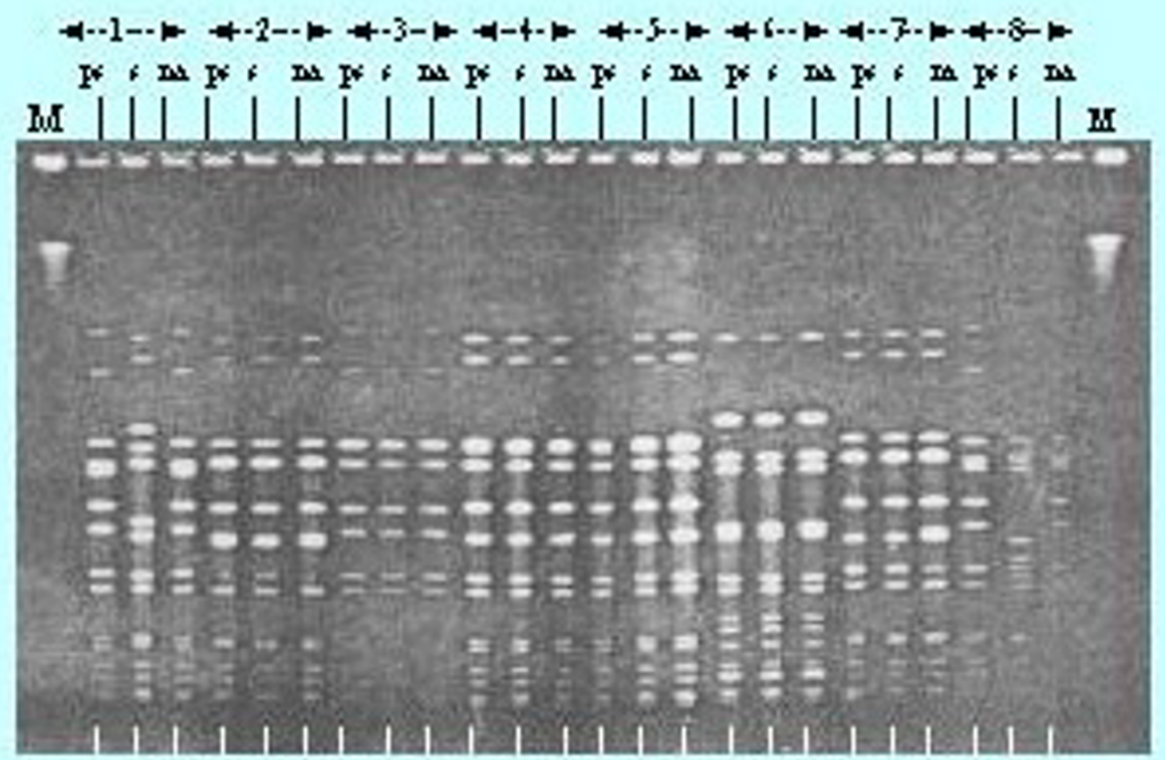

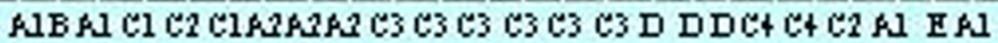

\section{Figure 5}

Pulsed-field gel electrophoresis (PFGE) of MRSA clinical isolates. PFGE patterns were indistinguishable between MRSA from the nasal cavity (na) and pus (Ps) but the patterns were different for MRSA from the skin (s) and nearby wounds for cases I and 8. PFGE patterns were indistinguishable between MRSA from the nasal cavity and pus and closely related to that of MRSA from the skin for case 2. PFGE patterns were indistinguishable between MRSA from the skin and pus but closely related to that of MRSA from the nasal cavity for case 7 . The patterns of MRSA isolates from the nasal cavity, skin, and pus were indistinguishable for cases $3,4,5, \& 6$.

onization at intensive care unit admission and is associated with severity of illness, length of stay, and exposures to antibiotics and medical devices [46].

Colonization with $S$. aureus can occur soon after birth and at any given time, the nasal carriage rate in adults is estimated at between $20 \%$ and $40 \%$ [47]. Healthcare workers have a higher incidence of colonization. The carrier state is clinically important because carriers undergoing surgery will experience more infections than non-carriers. Fierobe et al [42] has shown a relationship between MRSA postoperative intra-abdominal sepsis and nasal colonization of MRSA. MRSA strains are usually introduced into an institution by an infected or colonized patient or by a colonized healthcare worker, and transfer from one patient to another has led to major epidemics in tertiary care hospitals as well as chronic care facilities [3]. Colonization of anterior nares with MRSA carries a significantly higher risk for infection than does colonization by sensitive strains $[18,47]$.

It is imperative we continue with basic infection control principles like hand washing and contact isolation and barrier nursing. Intranasal 2\% mupirocin applied twice daily for five days appears to be the most effective topical agent against MRSA [48-50] and eliminates $91 \%$ of stable carrier states. By confining the investigation to nasal carriage in healthy state, colonization at other body sites may have remained undetected and the 'true' prevalence in this study may have been underestimated. There is, however, overall agreement that sensitivity of nose swabs in detecting MRSA carriage is reasonably high (>70\%) [51-53], and it was decided to confine the investigation to nasal specimens for reasons of accessibility, compliance and consistency with other investigations. The design of the study does not allow one to distinguish between patients who 


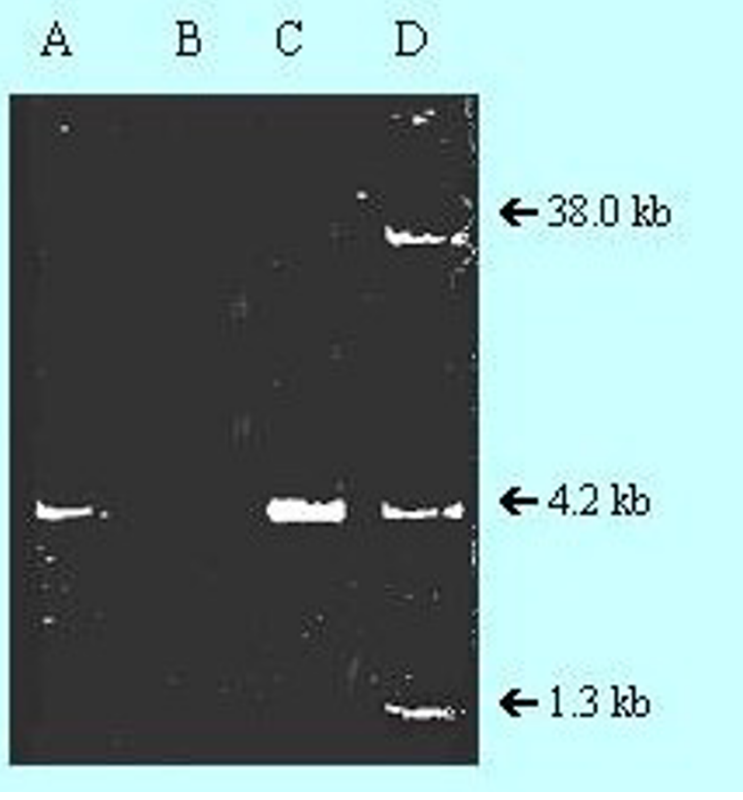

Figure 6

Agarose gel electrophoresis of crude plasmid DNA. Lane A, MRSA, resistant to A, G and Ak, having $4.3 \mathrm{~kb}$ plasmid (pJMR I0); Lane B, E. coli (DH5 $\alpha$ ) sensitive to $A, G$, and Ak; Lane C, Transformant E. coli (DH5 $\alpha$ ) having $4.3 \mathrm{~kb}$ plasmid; Lane D, S. aureus RN834, containing the plasmid molecular markers.

acquired MRSA during their current episode of hospital stay or patients already colonized on arrival to the hospital. Despite this, most of the carriers appeared to have acquired the organisms in hospital settings, as most of the isolates seem to be of the same types of strains as isolated from nose of the hospital workers.

From this study we suggest that all patients having history of previous hospital admission and patients admitted directly from nursing homes should be screened for MRSA prior to any elective surgical or orthopedic operative procedures. We believe that patients for routine elective procedures should have a negative result before undergoing the procedure. If surgery cannot be delayed due to medical reason then prophylaxis against MRSA should be given prior to the operation, though we appreciate this may not have much benefit in case of emergency admissions. However we would suggest that in patients with any of the above risk factors admitted for emergency surgery which may involve prosthetic implant, should be screened as well as given MRSA prophylaxis prior to their operations.

Broad-spectrum insusceptibility of all 180 MRSA and 76 MRCNS isolates to common antimicrobial agents were observed. Among all 17 antimicrobial agents used only vancomycin was shown to be consistently effective against all MRSA and MRCNS. We did not find any glycopeptide resistant $S$. aureus in our study, and vancomycin and teicoplanin remain the drugs of choice, although decreased susceptibility as well as resistance to vancomycin has been reported recently $[54,55]$.

Of the 850 stephylococcal isolates, surprisingly about $90 \%, 80 \%$ and $50 \%$ strains were resistant to Pencillin G, ampicillin and co-trimoxazole, respectively. This might be due to the fact that at present time these agents are tremendously used in the treatment of general infections. On the contrary to the multiple resistance of MRSA, MSSA seemed to be much more susceptible to all tested antimicrobial agents except for pencillin, ampicillin and co-trimoxozable. Our observation was that resistance in carrier isolates was lesser than clinical strains in case of all antibiotics tested. In the present study it is documented that resistance to chloramphenicol and ciprofloxacin was comparatively higher in ocular isolates as compared to staphylococcal strains isolated from other clinical sources. This might be due to more pronounced use of these antibiotics for treatment of ocular infections. This study underscores the need for hospital clinicians to be aware of the common bacterial isolates in their unit and their usual antibiotic susceptibility. This is imperative in order to make rational decisions for the prudent use of antibiotics, particularly for empirical therapy. Another important cause of resistance is excessive or inappropriate use of antibiotics in hospitals [56]. The magnitude of the problem of multi-resistance is such that clinicians must be familiar with the causes of antibiotic resistance and the measures for preventing or minimizing the emergence of resistance.

PFGE, because of its great discriminatory power and high degree of specimen typeability is accepted as the gold standard for the molecular typing of $S$. aureus isolates. It has successfully been used to study the epidemiology of $S$. aureus nosocomial infection and methicillin resistance [40,57-59]. Nevertheless, PFGE is time-consuming and labor intensive, in this study PFGE exhibited superiority as a technique for analyzing epidemiology of $S$. aureus. In the present study it was observed that the 61 strains of MRSA isolated in an Orthopaedic Surgical Ward displayed 42 patterns of antibiogram. These 61 MRSA strains were subjected to PFGE analysis whereby 14 PFGE patterns were observed. These results suggest that most of the MRSA appeared to have been acquired by patients during their current episode of hospital stay. Moreover similarity of PFGE patterns of MRSA isolates from pus, skin and nasal cavity suggest that most MRSA types isolated from pus were derived from the nasal cavity but some types were derived from the nearby skin and that these microorganisms occasionally cause wound infections. 


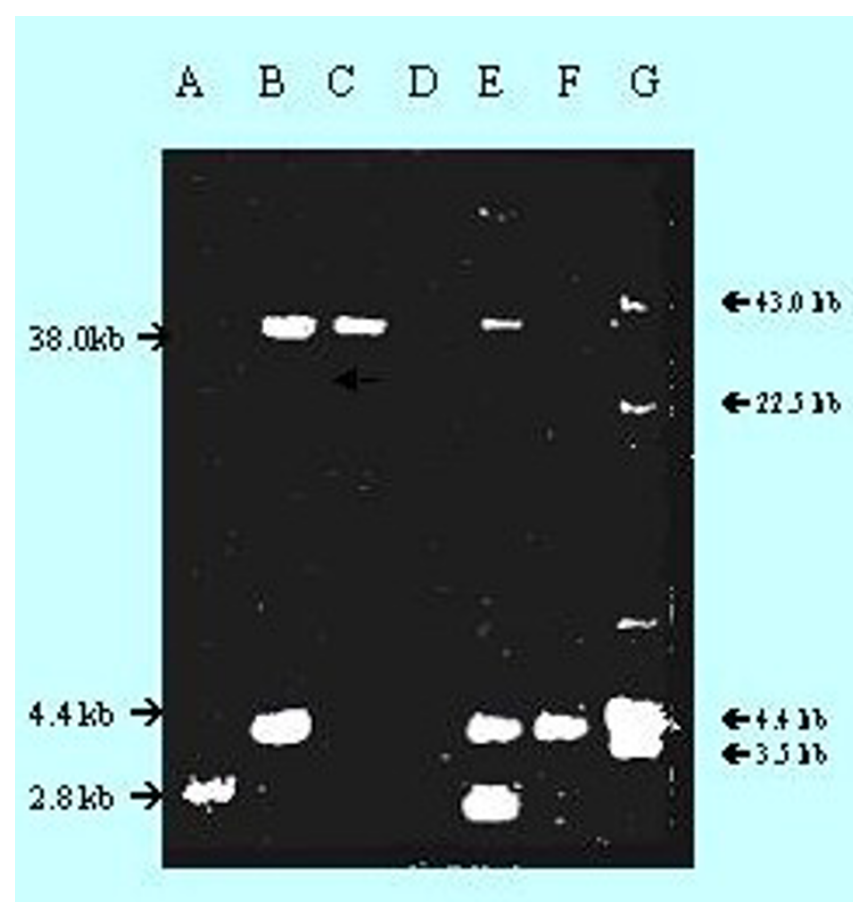

Figure 7

Plasmids transferred in conjugation through mixed culture test (MCT) experiments (broth matings). Lane A, Carrier S. aureus, JN-49 (AR, PR, CfR, ER, GS, TS), having $2.8 \mathrm{~kb}$ plasmid. Lane B, Clinical S. aureus, JS-I05 (TR, $\mathrm{E}^{\mathrm{R}}$, $\mathrm{GR}^{\mathrm{R}}, \mathrm{A}^{\mathrm{S}}, \mathrm{PS}, \mathrm{Cf}$ ), having $38 \mathrm{~kb}$ and $4.4 \mathrm{~kb}$ plasmid; Lane $\mathrm{C}$, Cured trasnconjugant, JNS-IA (GR, ER, CfR, $\left.T^{S}, A^{S}, P^{S}\right)$, having $38 \mathrm{~kb}$ plasmid; Lane D, Cured trasnconjugant, JNS-IB ( $E^{R}$, $\left.\mathrm{Cf}^{\mathrm{R}}, \mathrm{T}^{\mathrm{S}}, \mathrm{G}^{\mathrm{S}}, \mathrm{A}^{\mathrm{S}}, \mathrm{P}^{\mathrm{S}}\right)$, having no plasmid; Lane $\mathrm{E}$, Transconjugant JNS-I ( $\left.T^{R}, C^{R}, E^{R}, G^{R}, A^{R}, P^{R}\right)$, having $38 \mathrm{~kb}, 4.4 \mathrm{~kb}$ and 2.8 kb plasmid; Lane $F$, Cured Transconjugant JNS-IC (TR, CfR, $\left.E^{R}, G^{S}, A^{S}, P^{S}\right)$, having 4.4 kb plasmid; Lane $G$, Plasmid marker, S. aureus WBG 4483.

MRSA acquisition depends on 2 major and independent determinants: colonization pressure and antimicrobial selective pressure. In case of colonization with distinct multiple clones of MRSA, antimicrobial pressure plays a major role; in the case of colonization with a single dominant clone of MRSA, colonization pressure plays a major role. McGown [60] proposed a biological model to explain the relationship between antimocrobial use and the emergence of resistance. At the level of individual patient, antimicrobial treatment leads to a large modification in the endogenous flora. The usual result is that susceptible strains are replaced by resistant ones. At the collective level, antimicrobial use in a hospital unit tends to maintain the presence of multidrug - resistant organisms in inpatients, healthcare workers, and the environment. In cases in which basic infection-control practices are inconsistently applied, these pathogens are implicated in the majority of infections. Antimicrobials such as $\beta$ - lactams and fluoroquinolones, which are ineffective against MRSA and have excellent tissue diffusion, could promote the acquisition of MRSA by increasing the 'receptiveness' of the patients and thereby allowing the progression towards colonization and infection.

The spread of resistance to antimicrobial agents in $S$. aureus is largely due to the acquisition of plasmids and/or transposons [61]. Although transfer of resistance between staphylococcal strains in the laboratory has been shown to occur via transformation, transduction, and conjugation [62] only conjugative transfer appears to be significant in vivo [63]. In staphylococci, the conjugative transfer of resistant determinants is usually mediated by conjugative plasmids [64] but has also been shown to occur in the absence of detectable conjugative plasmids [65]. Conjugative plasmids, usually 35 to $50 \mathrm{~kb}$, spread resistance determinants between species and genera $[66,67]$. Besides transferring the resistance determinants, they can mobilize non-conjugative plasmids [64] recombine with nonconjugative plasmids to form new plasmids or acquire and transfer resistance transposons [61,63]. Studies with human staphylococcal strains indicate that Staphylococcus epidermidis is a reservoir of antibiotic resistance genes that can be transferred to $S$. aureus under in vitro and in vivo conditions [64]. In vitro studies of drug resistance transfer between clinical and carrier staphylococcal strains, was done in the present study. The results indicated that tetracycline resistance was transferred from clinical to carrier isolates. This reflects that the use of antibiotics in humans to treat infections can promote resistance in normal flora.

The widespread occurrence and dissemination of resistance markers leading to multiple antibiotics ineffective, thus increasing the cost of health care, needs to be tackled logistically by wise and judicious use of existing antibiotics and by developing ideal and cost effective antibiotics having least chances of acquiring resistance. Furthermore the hospital acquired MRSA infections through colonization of patients and hospital workers demands appropriate and timely measure to counteract this health problem.

\section{Competing interests}

The author(s) declare that they have no competing interests.

\section{Authors' contributions}

JAD carried out all the microbiological, molecular and clinical laboratory experiments as a part of his $\mathrm{PhD}$ thesis and has written the draft manuscript. MAT and JAK provided strains and helped in the design of the study. AA and MAK coordinated and participated in design of the study. MR and KHB participated in the design and coordination and helped in the draft of the manuscript. MJD and 
NA helped in design, data analysis and interpretation and planning of the molecular part of the study. SA provided overall leadership, laboratory infrastructure and coordination, and corrected the manuscript.

\section{All the authors read and approved the manuscript.}

\section{Acknowledgements}

We appreciate the support from technical staff of Microbial Division, Institute of Ophthalmology, Division of Bacteriology and Department of Microbiology J.N. Medical College, Aligarh Muslim University Aligarh, India; Department of Microbiology, Sher-e-Kashmir Institute of Medical Sciences, Srinagar, India and Lab of Molecular and Cell Biology (LMCB), Center for DNA Fingerprinting and Diagnostics, Hyderabad, India.

\section{References}

I. Diekema DJ, Pfller MA, Schmitz FJ, Smayevsky J, Bell J, Jones RN, Beach M, the SENTRY participants Group: Survey of infections due to Staphylococcus species: frequency of occurrence and antimicrobial susceptibility of isolates collected in United States, Canada, Latin America, Europe and Western Pacific Region for the SENTRY Antimicrobial Surveillance Program, 1997-1999. Clin Infect Dis 200I, 32(Suppl 2): I I4-I32.

2. Fekety FR Jr: The epidemiology and prevention of Staphylococcal infection. Medicine 1964, 43:593-613.

3. Harbarth S, Liassine N, Dharan S, Herrault P, Auckenthaler R, Pittet $D$ : Risk factors for persistant carriage of methicillin-resistant Staphylococcus aureus. Clin Infect Dis 200 I, 3 I: I 380-I385.

4. Kloos WE, Bannerman TL: Update on the clinical significance of coagulase-negative staphylococci. Clin Microbiol Rev 1994, 7:117-140.

5. Noble WC, Pitcher DG: Microbial ecology of the human skin. Adv Microb Ecol 1978, 2:245-489.

6. Betley MJ, Borst DW, Regassa LB: Staphylococal enterotoxins, toxic shock syndrome toxin and streptococcal pyogenic exotoxins: a comparative study of their molecular biology. In Biological Significance of Superantigens Edited by: Fleisher B. Karger, Basel; 1992: I-35

7. Ish-Horowicz MR, Melntyre P, Nade S: Bone and joint infections caused by multiply resistant Staphylococcus aureus in a neonatal intensive care unit. Pediatr Infect Dis J 1992, I 1:82-87.

8. Melish ME, Glasgow LA: The Staphylococcal scalded skin syndrome. Development of an experimental model. N Engl J Med 1970, 282: | || 4-I|| 9.

9. Keys TF, Hewitt WL: Endocarditis due to micrococci and Staphylococcus epidermidis. Arch Intern Med 1973, I32:216-223.

10. Boyce JM, Poller-Bynoe G, Opal SM, Dziobek L, Medeiros AA: A common-source outbreak of Staphylococcus epidermidis infections among patients undergoing cardiac surgery. J Infect Dis 1990, 161:493-499.

II. Black T: The Bacteriological flora of skin and its relation to post-operative wound infection. Trans Soc Occup Hygromycin 1966, 16:18-23.

12. Collins RN, Braun PA, Zinner SH, Kass EH: Risk of social and systemic infections with polyethylene intravenous catheters. $\mathrm{N}$ Engl ] Med 1978, 279:340-345

13. Weber DJ, Hoffman KL, Thoft RA, Baker AS: Endophthalmitis following intraocular lens implantation. Report of 30 cases and review of the literature. Rev Infect Dis 1986, 8: 12-20.

14. Limberg MB: A review of bacterial Keratitis and bacterial conjunctivitis. Am J Ophthalmol I99|, I I 2(4 Suppl):2S-9S

15. Marrie TJ, Kwan C, Noble MA, West A, Duffield L: Staphylococcus saprophyticus as a cause of urinary tract infections. J Clin Microbiol 1982, | 6:427-43|.

16. Wallmark GI, Anemark I, Talander B: Staphylococcus Saprophyticus: a frequent cause of urinary tract infection among female out patients. J Infect Dis 1978, 138:791-797.

17. Williams REO: Healthy Carriage of Staphylococcus aureus: its prevalence and importance. Bacteriol Rev 1963, 27:56-71.
18. Casewell MW, Hill RIR: The Carrier State: methicillin-resistant Staphylococcus aureus. J Antimicrob Chemother 1986, I8(suppl A): $1-12$.

19. Kluytmans J, Van Beljum A, Verbrugh H: Nasal Carriage of Staphylococcus aureus: epidemiology, underlying mechanisms and associated risks. Clin Microbial Re 1997, 10:505-520.

20. Lee YL, Cesario T, Lee R, Nothvogel S, Nassar J, Farsad N, Thrupp L: Colonization of Staphylococcus species resistant to methicillin or quinolone on hands of medical personnel in a skillednursing facility. Am J Infect Control 1994, 22:346-35I.

21. Perkins RF, Kundsin RB: Bacteriology of normal and infected conjunctiva. / Clin Microbiol 1975, I:I47-I49.

22. Bannerman TL, Rhoden DL, McAllister SK, Miller JM, Wilson LA: The source of coagulase-negative Staphylococci in the endophthalmitis virectomy study: a comparison of eyelid and intraocular isolates using pulsed field gel electrophoresis. Arch Ophthalmol 1997, I 15:357-361.

23. Berens C, Nilson El: Relationship between the bacteriology of the conjuctiva and nasal mucosa. Am J Ophthalmol 1944, 27:747-750.

24. Klimek JJ, Marsik FJ, Bartlett RC, Weir B, Shea P, Quintillani R: Clinical, epidemiologic and bacteriologic observations of an outbreak of methicillin-resistant Staphylococcus aureus at a large community hospital. Am J Med 1976, 61:340-345.

25. Jevons MP: Celbenin-resistant Staphylococci. Br Med J 196I, I: I24- 25.

26. Barber M: Methicillin-resistant Staphylococci. J Clin Pathol I96I, I4:385-393.

27. Woods GL, Hall GS, Rutherford I, Pratt KJ, Knapp CC: Detection of methicillin-resistant Staphylococcus epidermidis. J Clin Microbial 1986, 24:349-352.

28. Moreno F, Criso C, Jorgensen JH, Paterson JE: Methicllin-resistant Staphylococcus aureus as a community organism. Clin Infect Dis 1995, 21: 1308-1312.

29. Voss A, Milatovic D, Wallrauch-Schwarz C, Rosdahl VT, Braveny I: Methicillin-resistant Staphylococcus aureus in Europe. Eur J Clin Microbiol Infect Dis 1994, 13:50-55.

30. Schaefler S, Jones D, Perry W: Emergence of gentamicin and methicillin-resistant Staphylococcus aureus in New York City hospitals. J Clin Microbiol I98I, I 3:754-759.

31. Locather-Khorazo D, Thompson R: The bacterial flora of normal conjunctiva. Am J Ophthalmol 1935, I 8: III4-III6.

32. Krieg NR, ed: Bergey's Manual of Systematic Bacteriology Volume I. 8th edition. Baltimore: Williams and Wilkins; 1984.

33. Paik G: Reagent, stains and miscellaneous test procedures. In Manual of Clinical Microbiology 3rd edition. Edited by: Lenette EH, Balows A, Hausler WJ Jr, Truant JP. American Society for Microbiology, Washington, D.C; 1980:1000-1024.

34. National Committee for Clinical Laboratory Standards (NCCLS): Performance Standards for antimicrobial susceptibility testing. Document M7-A5, NCCLS, Wayne, PA, USA 2000

35. National Committee for Clinical Laboratory Standards (NCCLS): Methods for dilution antimicrobial susceptibility tests for bacteria that grow aerobically. NCCLS, Documents M7-A5. NCCLS, Wayne, Pa 2000.

36. Birnboim $\mathrm{HC}$ : A rapid alkaline extraction method for the isolation of plasmid DNA. Methods Enzyme 1983, 100:243-255

37. Takahashi S, Nagano Y: Rapid procedure for isolation of plasmid DNA. I Clin Microbiol 1984, 20:608-6/3.

38. Maniatis T, Fritsch EF, Sambrook J: Molecular Cloning, A Laboratory Manual Volume 3. 2nd edition. Cold Spring Harbor Laboratory Press, New York; 1989.

39. Forbes BA, Schaberg DR: Transfer of resistance plasmids from Staphylococcus epidermidis to Staphylococcus aureus evidence for conjugative exchange of resistance. J Bacteriol 1983, 153:627-634.

40. Bannerman TL, Hancock GA, Tenover FC, Miller JM: Pulsed-field gel electrophoresis as a replacement for bacteriophage typing of Staphylococcus aureus. J Clin Microbiol I 995, 33:55I-555.

4I. Tenover FC, Arbeit R, Archer G, Biddle J, Byrne S, Goering R, Hancock G, Hebert GA, Hill B, Hollis R: Comparison of traditional and molecular methods of typing isolates of Stphyylococcus aureus. I Clin Microbiol 1994, 32:407-4I5.

42. Fierobe L, Decre D, Muller C, Lucet JC, Marmuse JP, Mantz J, Desmonts JM: Methicillin-resistant Staphylococcus aureus as caus- 
ative agent of postoperative intra-abdominal infection: relation to nasal colonization. Clin Infect Dis 1999, 29: I 23 I- 1238.

43. Thompson RL, Cabezudo I, Wenzel RP: Epidemiology of nosocomial infections caused by methiciliin-resistant Staphylococcus aureus. Ann Intern Med 1982, 97:309-317.

44. Jernigan JA, Pullen AL, Partin C, Jarvis WR: Prevalence of and risk factors for colonization with methicillin - resistant Staphylococcus aureus in an outpatient clinic population. Infect Control Hosp Epidemiol 2003, 24:445-450.

45. Corbella X, Dominguez MA, Pujol M, Ayats J, Sendra M, Pallares R, Ariza J, Gudiol F: Staphylococcus aureus nasal carriage as a marker for subsequent infections in intensive care unit patients. Eur J Clin Microbiol Infect Dis 1997, 16:35I-357.

46. Ho PL, for the Hong Kong Intensive Care Unit Antimicrobial Resistance Study(HKICARE) Group: Carriage of methicillin - resistant Staphylococcus aureus, Ceftazidime - resistant Gram - negative bacilli, and vancomycin - enterococci before and after intensive care unit admission. Crit Care Med 2003, 3 I : I 175- I I 82.

47. Asensio A, Guerrero A, Quereda C, Lizan M, Martinez-Ferrer M: Colonization and infection with methicillin-resistant Staphylococcus aureus: associated factors and eradication. Infect Control Hosp Epidemiol 1996, 17:20-28.

48. Casewell MW, Hill RLR: Elimination of nasal carriage of Staphylococcus aureus with mupirocin ('pseudomonic acid') - a controlled trial. J Antimicrob Chemother 1986, 17:365-372.

49. Herwaldt LA: Control of methicillin-resistant S. aureus in the hospital setting. Am J Med 1999, 106: I IS- I8S. Discussion, 485-525

50. Report: Guidelines for the control of epidemic methicillin resistant Staphylococcus aureus. J Hosp Infect 1986, 7:193-201.

5I. Calia FM, Wolinsky E, Mortimer EA Jr, Abrams JS, Rammelkamp CH Jr: Importance of the carrier state as a source of Staphylococcus aureus in wound sepsis. J Hyg 1969, 67:49-57.

52. Coello R, Glynn JR, Gaspar C, Picazo Jj, Fereres J: Risk factors for developing clinical infection with methicillin-resistant Staphylococcus aureus amongst hospital patients initially only colonized with MRSA. J Hosp Infect 1997, 37:39-46.

53. Singh K, Gavin PJ, Vescio T, Thomson RB Jr, Deddish RB, Fisher A, Noskin GA, Peterson LR: Microbiologic surveillance using nasal cultures alone is sufficient for detection of methicillin-resistant Staphylococcus aureus isolates in neonates. I Clin Microbiol 2003, 41:2755-2757.

54. Smith TL, Pearson ML, Wilcox KR, Cruz C, Lancaster MV, RobinsonDunn B, Tenover FC, Zervos MJ, Band JD, White E, Jarvis WR: Emergence of vancomycin resistance in Staphylococcus aureus. New Eng / Med 1999, 340:493-50I.

55. Center for Disease Control and Prevention: Staphylococcus aureus resistant to vancomycin - United States. Morb Mortal Wkly Rep 2002, 5I:565-567.

56. Tenover FC, Mc Growan JE Jr: Reasons for the emergence of antibiotic resistance. Am J Med Sci 1996, 3 I I:9-16.

57. Bialkowska-Hobrzanska $H$, Jaskot $D$, Hammerberg O: Evaluation of restriction endonuclease fingerprinting of chromosomal DNA and plamid profile analysis for characterization of multi-resistant coagulase-negative staphylococci in bacteremic neonates. J Clin Microbiol 1990, 28:269-275.

58. Ichiyama S, Ohta M, Shimokata K, Kato N, Takeuchi J: Genomic DNA fingerprinting by pulsed field gel electrophoresis as an epidemiological marker for study of nosocomial infections caused by methicillin-resistant Staphylococcus aureus. J Clin Microbiol I991, 29:2690-2695.

59. Lessing MPA, Jordens JZ, Bowler IC]: Molecular epidemiology of multiple strain outbreaks of methicillin-resistant Staphylococcus aureus amongst patients and staff. J Hosp Infect 1995, 3I:253-260

60. McGown JE: Antimicrobial resistance in hospital organisms and its relationship to antibiotic use. Rev Infect Dis 1983, 5: $1033-1047$.

61. Lyon BR, Skurray R: Antimicrobial resistance of Staphylococcus aureus: genetic basis. Microbiol Rev 1987, 5 I:88-134.

62. Lacey RW: Evidence for two mechanisms of plasmid transfer in mixed cultures of Staphylococcus aureus. J Gen Microbiol 1980, I 1 9:423-435.

63. Townsend DE, Bolton S, Ashdown N, Grubb WB: Transfer of plasmid-borne aminoglycoside-resistance determinants in staphylococci. J Med Microbiol 1985, 20(2):169-85.
64. Forbes BA, Schaberg DR: Transfer of resistance plasmids from Staphylococcus epidermidis to Staphylococcus aureus evidence for conjugative exchange of resistance. J Bacteriol 1983, 153:627-634.

65. El Solh N, Fouace JM, Pillet J, Chabbert YA: Plasmid DNA content of multiresistant Staphylococcus aureus strains. Ann Inst Pasteur Microbiol | 98I, |32B:| 3|-I56.

66. Gillespi MT, May JW, Skurray RA: Antibiotic susceptibilities and plamid profiles of nosocomial methicillin-resistant Staphylococcus aureus: a retrospective study. J Med Microbiol 1984, 17:295-310.

67. Udo EE, Grubb WB: Conjugal transfer of plasmid pWBG637 from Staphylococcus aureus to Staphyloccus epidermidis and Streptococcus faecalis. FEMS Microbiol Lett 1990, 60:183-187.
Publish with Bio Med Central and every scientist can read your work free of charge

"BioMed Central will be the most significant development for disseminating the results of biomedical research in our lifetime. "

Sir Paul Nurse, Cancer Research UK

Your research papers will be:

- available free of charge to the entire biomedical community

- peer reviewed and published immediately upon acceptance

- cited in PubMed and archived on PubMed Central

- yours - you keep the copyright 